Nutrient and Suspended-Sediment Trends, Loads, and Yields and Development of an Indicator of Streamwater Quality at Nontidal Sites in the Chesapeake Bay Watershed, 1985-2010

Scientific Investigations Report 2012-5093 



\section{Nutrient and Suspended-Sediment Trends, Loads, and Yields and Development of an Indicator of Streamwater Quality at Nontidal Sites in the Chesapeake Bay Watershed, 1985-2010}

By Michael Langland, Joel Blomquist, Douglas Moyer, and Kenneth Hyer

Scientific Investigations Report 2012-5093 


\section{U.S. Department of the Interior \\ KEN SALAZAR, Secretary \\ U.S. Geological Survey \\ Marcia K. McNutt, Director}

\section{U.S. Geological Survey, Reston, Virginia: 2012}

For more information on the USGS — the Federal source for science about the Earth, its natural and living resources, natural hazards, and the environment, visit http://www.usgs.gov or call 1-888-ASK-USGS.

For an overview of USGS information products, including maps, imagery, and publications, visit http://www.usgs.gov/pubprod

To order this and other USGS information products, visit http://store.usgs.gov

Any use of trade, product, or firm names is for descriptive purposes only and does not imply endorsement by the U.S. Government.

Although this report is in the public domain, permission must be secured from the individual copyright owners to reproduce any copyrighted materials contained within this report.

Suggested citation:

Langland, Michael, Blomquist, Joel, Moyer, Douglas, and Hyer, Kenneth, 2012, Nutrient and suspended-sediment trends, loads, and yields and development of an indicator of streamwater quality at nontidal sites in the Chesapeake Bay watershed, 1985-2010: U.S. Geological Survey Scientific Investigations Report 2012-5093, 26 p. 


\section{Contents}

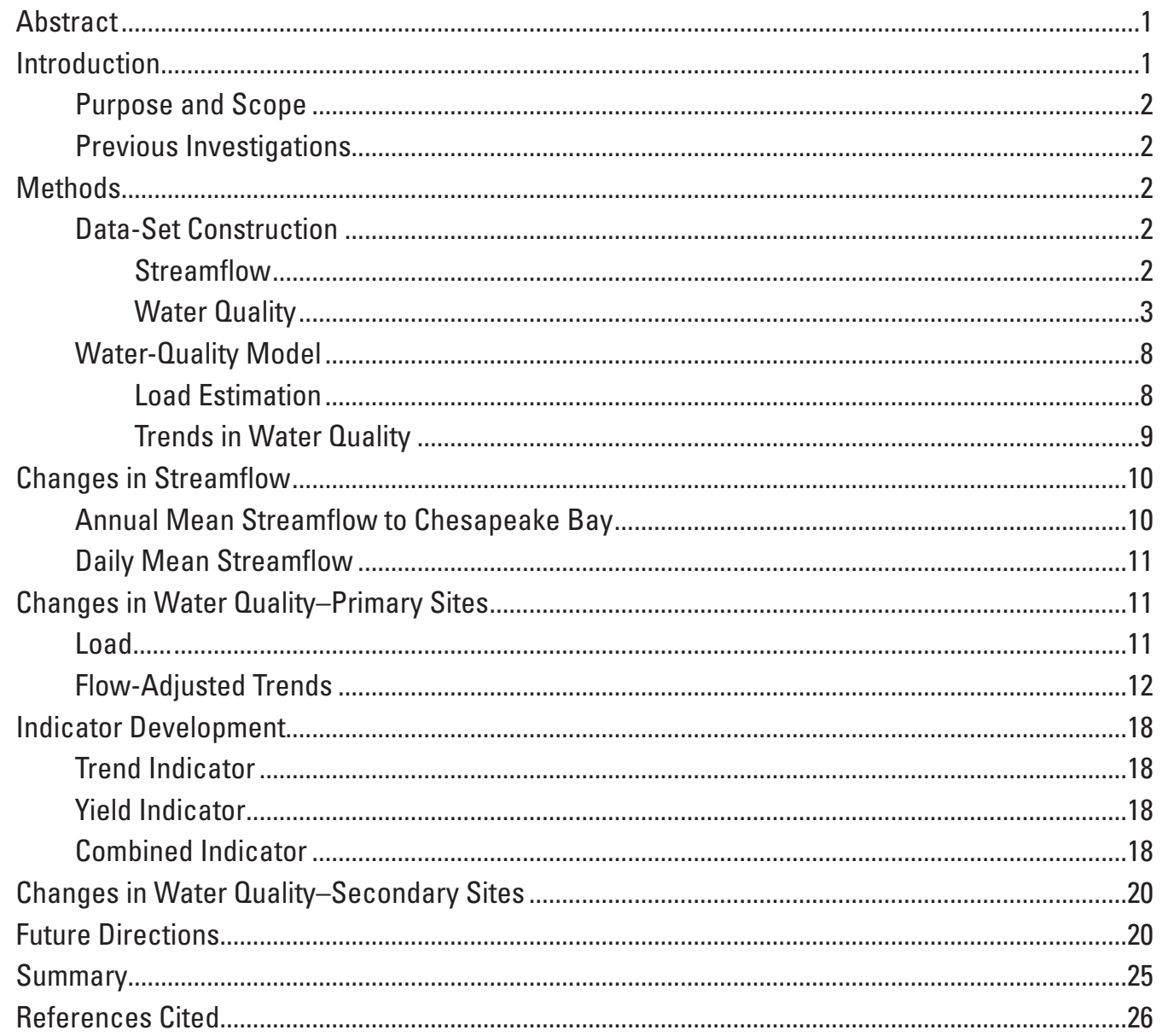




\section{Figures}

1. Map showing current (2010) Chesapeake Bay nontidal monitoring network with sites having an adequate period of record for trend and (or) load computation.

2. Graph showing estimated annual mean streamflow to Chesapeake Bay from 1937 to 2010

3. Graph showing annual combined total nitrogen loads and streamflow at the nine River Input Monitoring sites, 1990-2010.

4. Graph showing annual combined total phosphorus loads and streamflow at the nine River Input Monitoring sites, 1990-2010.

5. Graph showing annual combined total sediment loads and streamflow at the nine River Input Monitoring sites, 1990-2010.

6. Map showing flow-adjusted trends in total nitrogen concentration for 31 nontidal sites, 1985-2010.

7. Map showing flow-adjusted trends in total phosphorus concentration for 31 nontidal sites, 1985-2010

8. Map showing flow-adjusted trends in sediment concentration for 31 nontidal sites, 1985-2010

9. Map showing combined nitrogen trends (WY2001-10) and yields (WY2006-10) at 64 stream monitoring sites in the Chesapeake Bay watershed.

10. Map showing combined phosphorus trends (WY2001-10) and yields (WY2006-10) at 64 stream monitoring sites in the Chesapeake Bay watershed

11. Map showing combined sediment trends (WY2001-10) and yields (WY2006-10) at 64 stream monitoring sites in the Chesapeake Bay watershed 


\section{Tables}

1. Chesapeake Bay Nontidal Monitoring Program sites, indicating site group and type, type of analysis, and number of sites included in the analysis, 1985-2010...............3

2. Chesapeake Bay Nontidal Monitoring Network stations, grouped by type of

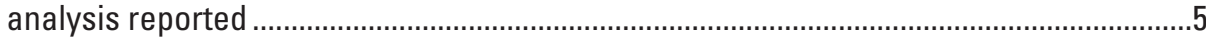

3. Nitrogen, phosphorus, and sediment species tested for trend ........................................

4. Flow-adjusted trends for the nine River Input Monitoring sites, 1990-2010_...................13

5. Flow-adjusted trends for water years $1985-2010$ and $2001-10$ at 33 streammonitoring sites in the Chespeake Bay watershed .........................................................15

6. Mean yields of nitrogen, phosphorus, and sediment at 64 stream-monitoring sites in the Chesapeake Bay watershed, 2006-10.

7. Combined trend and yield indicator counts by classification for the 64 sites in the Chesapeake Bay watershed

8. Trend results for the 16 Virginia secondary sites in the Chesapeake Bay Nontidal Monitoring Program 



\title{
Nutrient and Suspended-Sediment Trends, Loads, and Yields and Development of an Indicator of Streamwater Quality at Nontidal Sites in the Chesapeake Bay Watershed, 1985-2010
}

\author{
By Michael Langland, Joel Blomquist, Douglas Moyer, and Kenneth Hyer
}

\section{Abstract}

The U.S. Geological Survey (USGS) updates information on loads of, and trends in, nutrients and sediment annually to help the Chesapeake Bay Program (CBP) investigators assess progress toward improving water-quality conditions in the Chesapeake Bay and its watershed. CBP scientists and managers have worked since 1983 to improve water quality in the bay. In 2010, the U.S. Environmental Protection Agency (USEPA) established a Total Maximum Daily Load (TMDL) for the Chesapeake Bay. The TMDL specifies nutrient and sediment load allocations that need to be achieved in the watershed to improve dissolved oxygen, water-clarity, and chlorophyll conditions in the bay. The USEPA, USGS, and state and local jurisdictions in the watershed operate a CBP nontidal water-quality monitoring network and associated database that are used to update load and trend information to help assess progress toward reducing nutrient and sediment inputs to the bay.

Data collected from the CBP nontidal network were used to estimate loads and trends for two time periods: a long-term period (1985-2010) at 31 "primary" sites (with storm sampling) and a 10-year period (2001-10) at 33 primary sites and 16 "secondary" sites (without storm sampling). In addition, loads at 64 primary sites were estimated for the period 2006 to 2010.

Results indicate improving flow-adjusted trends for nitrogen and phosphorus for 1985 to 2010 at most of the sites in the network. For nitrogen, 21 of the 31 sites showed downward (improving) trends, whereas 2 sites showed upward (degrading) trends, and 8 sites showed no trends. The results for phosphorus were similar: 22 sites showed improving trends, 4 sites showed degrading trends, and 5 sites indicated no trends. For sediment, no trend was found at 40 percent of the sites, with 10 sites showing improving trends and 8 sites showing degrading trends.

The USGS, working with CBP partners, developed a new water-quality indicator that combines the results of the 10-year trend analysis with results from a greater number of sites (64 primary sites) where loads and yields of total nitrogen and phosphorus and sediment could be calculated. The new indicator shows fewer significant trends for the 10-year time period than for the long-term time period (1985-2010). For 2001-10, total nitrogen trends were downward (improving) at 14 sites and upward (degrading) at 2 sites; no trend was found at 17 sites. For total phosphorus, 12 sites showed improving trends, 4 sites showed degrading trends, and 17 sites showed no trend. For total sediment, most sites (21) did not exhibit a significant trend; 3 sites showed improving trends, and 10 sites showed degrading trends. Few significant trends were seen at the 16 secondary sites: improving trends for total nitrogen at 4 sites, improving trends for total phosphorus at 2 sites, and a degrading trend for sediment at 1 site.

Total streamflow to the Chesapeake Bay was 20 percent higher in 2010 than in 2009 and is considered to be within the normal range of flow, whereas annual streamflow at 28 sites was greater in 2010 than in 2009. No trends in daily streamflow were detected at the 31 long-term sites. Combined loads for the farthest downstream nontidal monitoring sites (called "River Input Monitoring sites") increased 33 percent for total nitrogen, 120 percent for total phosphorus, and 330 percent for total sediment from 2009 to 2010. The large increase in phosphorus and sediment loads in 2010 was caused in large part by two large storm events that occurred during the spring in the Potomac River Basin. Yields (load per watershed area) of total nitrogen in the Chesapeake Bay watershed decreased from north to south (New York to Virginia). No spatial patterns were discernible for total phosphorus or sediment.

\section{Introduction}

The Chesapeake Bay has been adversely affected by nutrient and sediment enrichment. Excess nutrients stimulate algal blooms that decay and consume dissolved oxygen, causing areas of low dissolved-oxygen concentration in the 
bay. Algal blooms and sediment reduce sunlight needed by underwater grasses. In the mid-1980s, the Chesapeake Bay Program (CBP), a partnership among the Commonwealths of Pennsylvania and Virginia, the State of Maryland, the District of Columbia, the Federal Government, and the Chesapeake Bay Commission, began efforts to reduce inputs of nutrients and sediment to the bay. In the 1990s, the States of New York, West Virginia, and Delaware joined in the water-quality activities of the CBP. In 2010, the U.S. Environmental Protection Agency (USEPA) established a Total Maximum Daily Load (TMDL) requiring all jurisdictions in the bay watershed to develop and implement Watershed Implementation Plans (WIPs) to have practices in place to reduce the loads of nutrients and sediment entering the bay by 2025 .

The U.S. Geological Survey (USGS) routinely reports long-term trends and monthly and annual nutrient and sediment loads for stream-quality monitoring stations across the Chesapeake Bay watershed. The USGS first reported trends in the late 1980s at nine locations in Maryland and Virginia. Water-quality activities and load and trend analyses at these nine sites are referred to collectively as the "River Input Monitoring (RIM) program." Multivariate regression techniques have been developed for load and trend data analysis. The trend technique attempts to adjust for the influences of streamflow and season (flow-adjusted trend) to help water managers understand how trends in nutrient and sediment concentrations and loads relate to management actions that aim to restore and protect water quality.

In 2004, new analysis techniques were applied, and the number of sites was expanded to include additional nontidal sites upstream from the RIM sites (Langland and others, 2006). Annual updates of loads and flow-adjusted trends for these 33 sites are made public both in print and on the Internet. The methods used to estimate trends in streamflow, load, and flow-weighted concentration are documented. In 2004, the CBP partners formalized the CBP Nontidal Water-Quality Network (U.S. Environmental Protection Agency, 2004).

Common sampling frequencies and protocols and nutrient and sediment analyses were established for all sites in the network. USGS and USEPA, in cooperation with the States, river basin commissions, and other partners, have worked to expand the network since 2004 .

\section{Purpose and Scope}

This report presents results of load and trend analyses for nutrients and sediment at sites in the Chesapeake Bay Nontidal Water-Quality Network (CB-NTN) for 1985-2010 and documents (1) changes in the methods used to calculate loads and trends since 2004 and (2) the development of a new water-quality indicator that can be used to assess current streamwater-quality conditions at the sites, as well as progress toward meeting the TMDL.

Loads and trends were evaluated for the expanded number of sites in the network for three time periods, and the following results are presented in this report: (1) loads and trends for the period of record (generally 1985-2010) at 31 sites; (2) loads and trends for a 10-year period (2001-10) at 33 primary sites and 16 secondary sites; and (3) loads for a 5-year period (2006-10) at 64 sites. The loads and trends from 33 10-year time period sites and the yields from the 645 -year time period sites are used in the development of a new water-quality indicator for the Chesapeake Bay.

\section{Previous Investigations}

In the late 1980s, the USGS first reported loads and analyzed for trends at nine locations in Maryland and Virginia, collectively referred to as the River Input Monitoring (RIM) program. In 1995, the network was expanded to include waterquality data from more than 1,000 new sites, resulting in loads and trend results from 127 sites (Langland and others, 1995). Annual updates of loads and trends were completed each year from 1995 to 2003 with minimal change in techniques. In 2004, when the CBP partners formalized the CBP Nontidal Water-Quality Network, new analysis techniques were applied, and the number of sites was expanded to include an additional 24 nontidal sites upstream from the 9 RIM sites (Langland and others, 2006).

\section{Methods}

This section describes (1) the methods used to construct the data sets that were analyzed to assess streamflow and water quality, (2) the methods used to analyze the streamflow and water-quality data sets, and (3) the development of the new streamwater trend and yield water-quality indicator.

\section{Data-Set Construction}

This section discusses the construction of streamflow and water-quality data sets for input into various models to determine statistical results. In addition, construction of a water-quality database is described, specific site information is presented, and methods used to sum nitrogen and phosphorus species are discussed.

\section{Streamflow}

Daily mean streamflow data are retrieved annually from the USGS National Water Information System (NWIS) database (http://waterdata.usgs.gov/nwis/). For this study, the data were retrieved once for the period of record (POR); the 10 - and 5-year periods of record analyzed were subsets of the same file.

The streamflow files were analyzed to detect and evaluate any significant water-quality trend(s). In previous studies, streamflow was analyzed by using linear regression to determine the trend in streamflow. Evaluation of time series 
of daily mean streamflows for this study showed that the data residuals generally were autocorrelated, which may lead to significant loss of power in trend testing. The approach used to overcome autocorrelation was to increase the averaging period (Helsel and Hirsch, 2002).

Time series of seasonal mean streamflow were constructed by using an AR60 (autoregressive with 60 daily lags) model. Time series were constructed for daily mean streamflow at each site as well as for annual streamflow to determine total freshwater flow to the bay. The annual streamflow time series provide a basis for evaluating interannual variability; the daily time series allow the analysis of records for long-term trends.

\section{Water Quality}

In 1992, the USGS built a "nontidal database" containing selected water-quality and biological data (Langland and others, 1995). Fifty-eight physical, biological, and chemical water-quality constituents, properties, and characteristics are stored in this database. The USGS requests water-quality data annually from the cooperating agencies in the Chesapeake Bay watershed that collect nontidal monitoring data. Data typically are received in ASCII files. The data are then read into a Statistical Analysis System (SAS) database. Data are appended if the site is a previously existing site or, if the site is new, it is added to the database. When the water-quality files are read into the SAS database, a series of programs performs an initial quality assurance/quality control check on the data by searching for outliers, missing dates or times, and suspect remark codes. Currently (2010), there are approximately 1,400 sites in the Chesapeake Bay watershed. The database consists of water-quality and streamflow data from sites with a minimum of 3 consecutive years of sampling from 1972 through the current year. New sites are added to the database if at least 12 samples have been collected over 3 continuous years and at least 1 sample has been collected in each season in the 3 years (spring, summer, fall, and winter). Although many sites are sampled on a routine (usually monthly or bimonthly) basis, many do not have a continuous streamflow record and, therefore, cannot be used in the computation of annual loads and trends. The CB-NTN currently contains approximately 120 sites. A subset of 80 of sites having adequate data for estimation of loads and trends was used in this study.

For data-analysis and -reporting purposes, the CB-NTN sites were organized into two groups: primary sites, consisting of (1) the RIM program sites and (2) the Multi-Agency Nontidal Monitoring Program sites, and secondary sites. Both primary and secondary sites are used to provide information from the nontidal areas of the bay (table 1). Primary sites are sampled monthly, supplemented with stormflow samples; secondary sites also are sampled monthly, but no targeted stormflow samples are collected. Therefore, only trends (not loads) are estimated. All sites must conform to the sampling protocols established by the CB-NTN. A subset of approximately 31 primary sites with long-term ( 20 or more years) waterquality and streamflow data are used to determine annual and seasonal changes in streamflow and constituent concentrations and to estimate POR or long-term trends. As part of the RIM program, data from nine sites with streamwater-quality and streamflow data near the farthest downstream limit of nontidal waters are analyzed. The Multi-Agency Nontidal Monitoring Program added 22 sites with long-term water-quality and streamflow data (long-term monitoring in figure1 and table 2). In addition to the POR sites, primary-site lists were developed for two other time periods. Defining a 10 -year time period resulted in two additional sites, whereas defining a 5-year time period resulted in 31 additional sites (short-term monitoring in figure 1 and table 2). A 10-year timeframe was used for the secondary sites and was not used in the indicator development; therefore, the discussion of secondary sites follows the discussion of indicator development in this report (secondary monitoring in figure 1 and table 2). The primary goal of the network is to provide CBP managers with water-quality monitoring information to help assess progress toward nutrient and sediment reductions required to meet the bay TMDL.

The species (forms) of nitrogen, phosphorus, and sediment evaluated for trends are shown in table 3. Because the analytical methods used to determine concentrations of

Table 1. Chesapeake Bay Nontidal Monitoring Program sites, indicating site group and type, type of analysis, and number of sites included in the analysis, 1985-2010.

\begin{tabular}{lll}
\hline \multicolumn{1}{c}{ Site group } & \multicolumn{1}{c}{ Site type } & \multicolumn{1}{c}{ Type of analysis } \\
\hline Primary & River Input Monitoring (RIM) & Long- (1985-2010) and short-term (2001-10) trends and loads \\
& Multi-Agency Nontidal Monitoring & Long- and short-term trends and loads \\
& & Short-term trends and loads \\
& & Short-term loads (2006-10) \\
Secondary & Multi-Agency Nontidal Monitoring & Short-term trends and loads \\
\hline
\end{tabular}




\section{EXPLANATION}

\section{River basin}

Susquehanna

Western Shore

Choptank

Patuxent

Potomac

Rappahannock

Mattaponi

Pamunkey

James

Appomattox

Chesapeake Bay

Chesapeake Bay watershed boundary

Stream

Site and site number

48 River Input Monitoring

${ }^{19}$ L Long-term Monitoring

38 Short-term Monitoring

S16 $\triangle$ Secondary sites
Base from U.S. Geological Survey digital data, 1972, 1:2,000,000 Albers Equal-Area Conic Projection. Standard parallels 29 degrees 30 minutes N, central meridian 75 degrees 00 minutes $\mathrm{W}$.

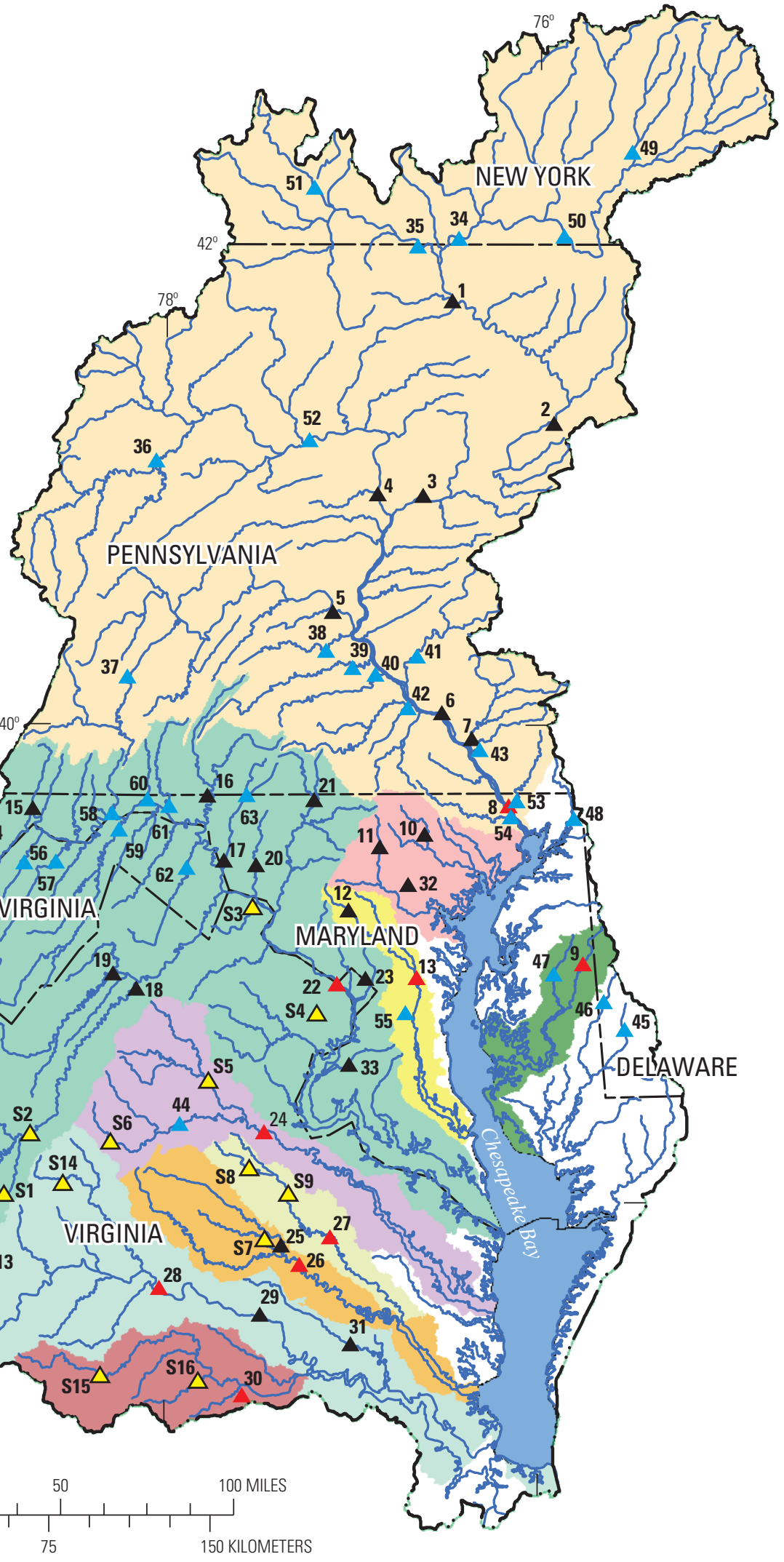

Figure 1. Current (2010) Chesapeake Bay nontidal monitoring network with sites having an adequate period of record for trend and (or) load computation. (Corresponding station information is included in table 2) 


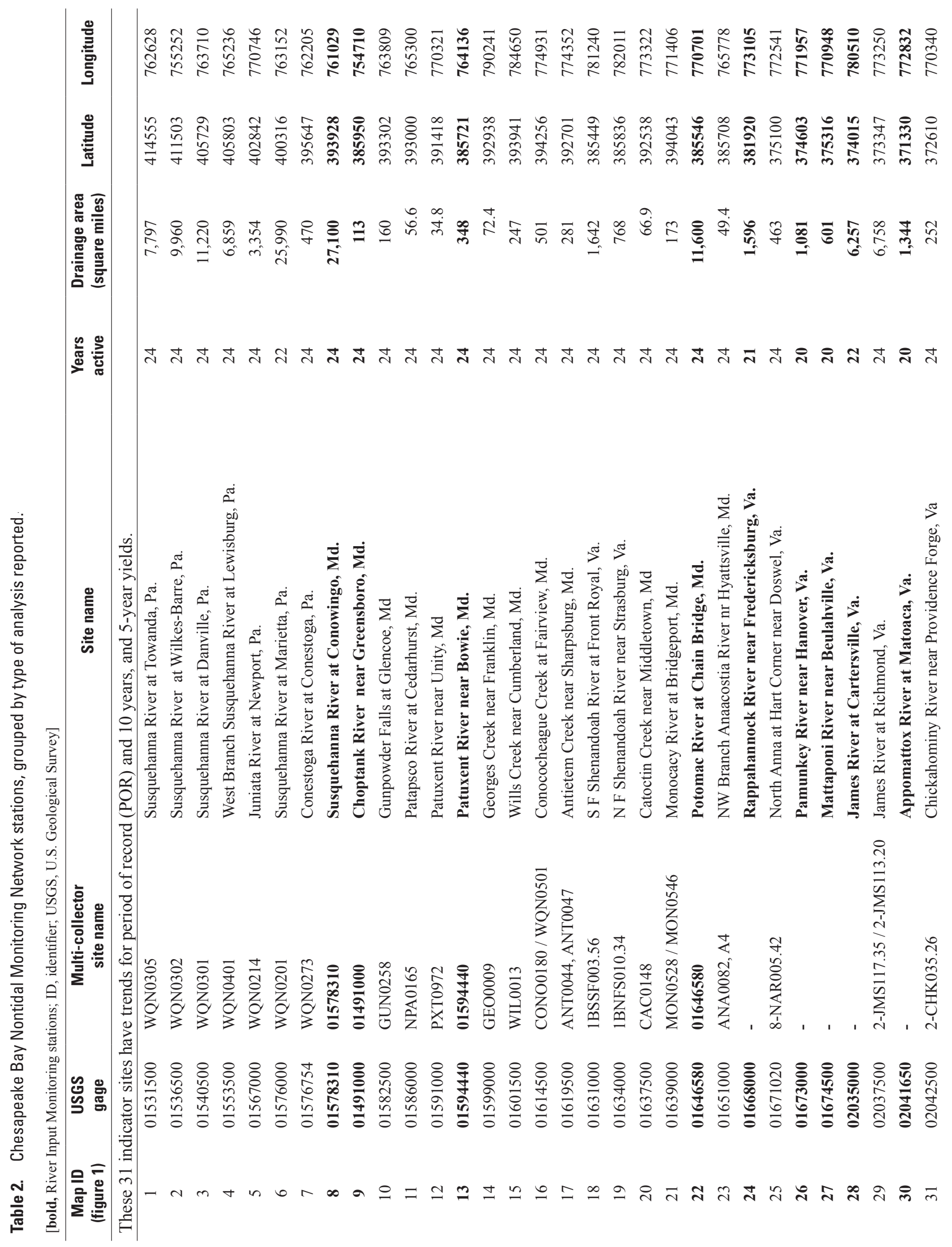




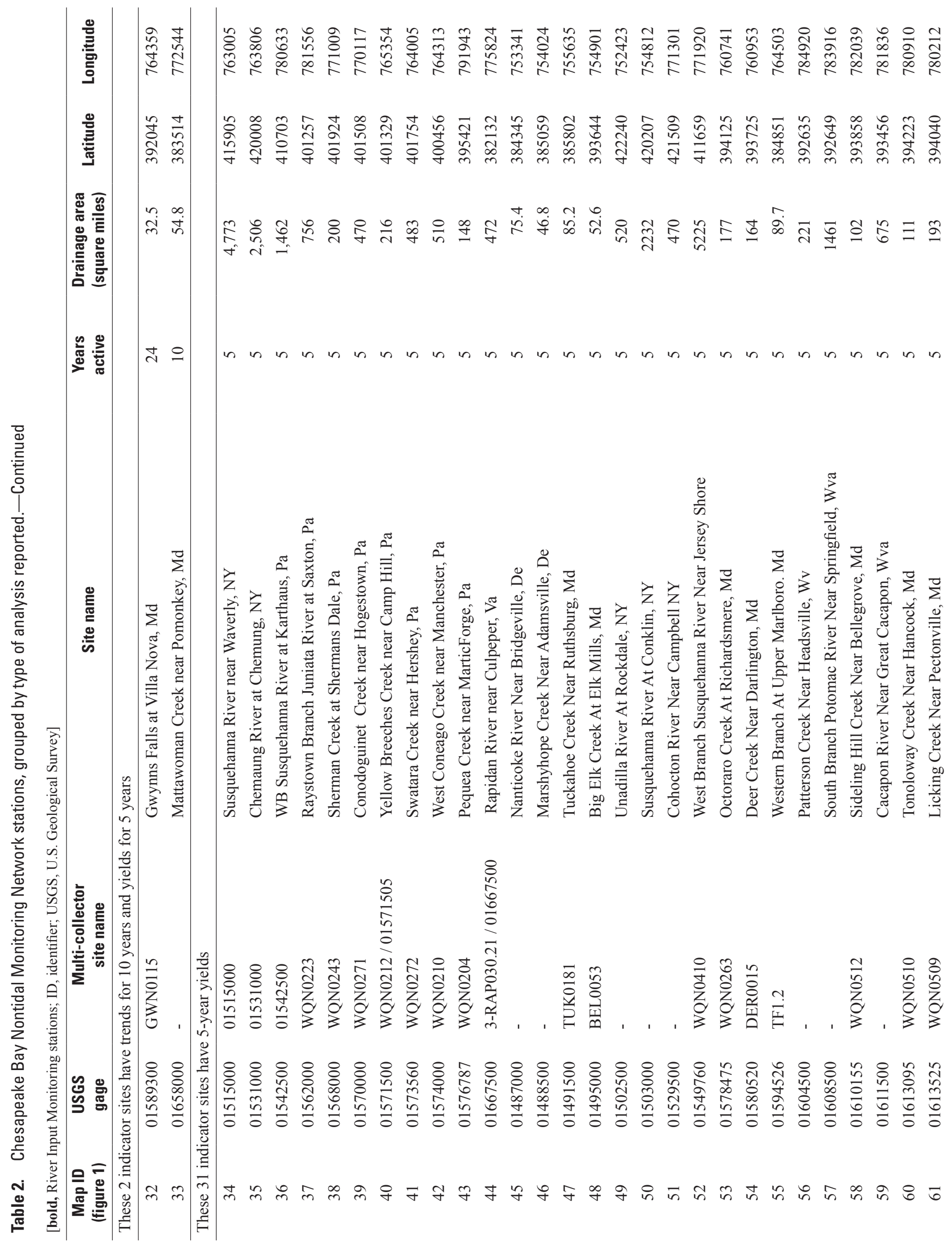




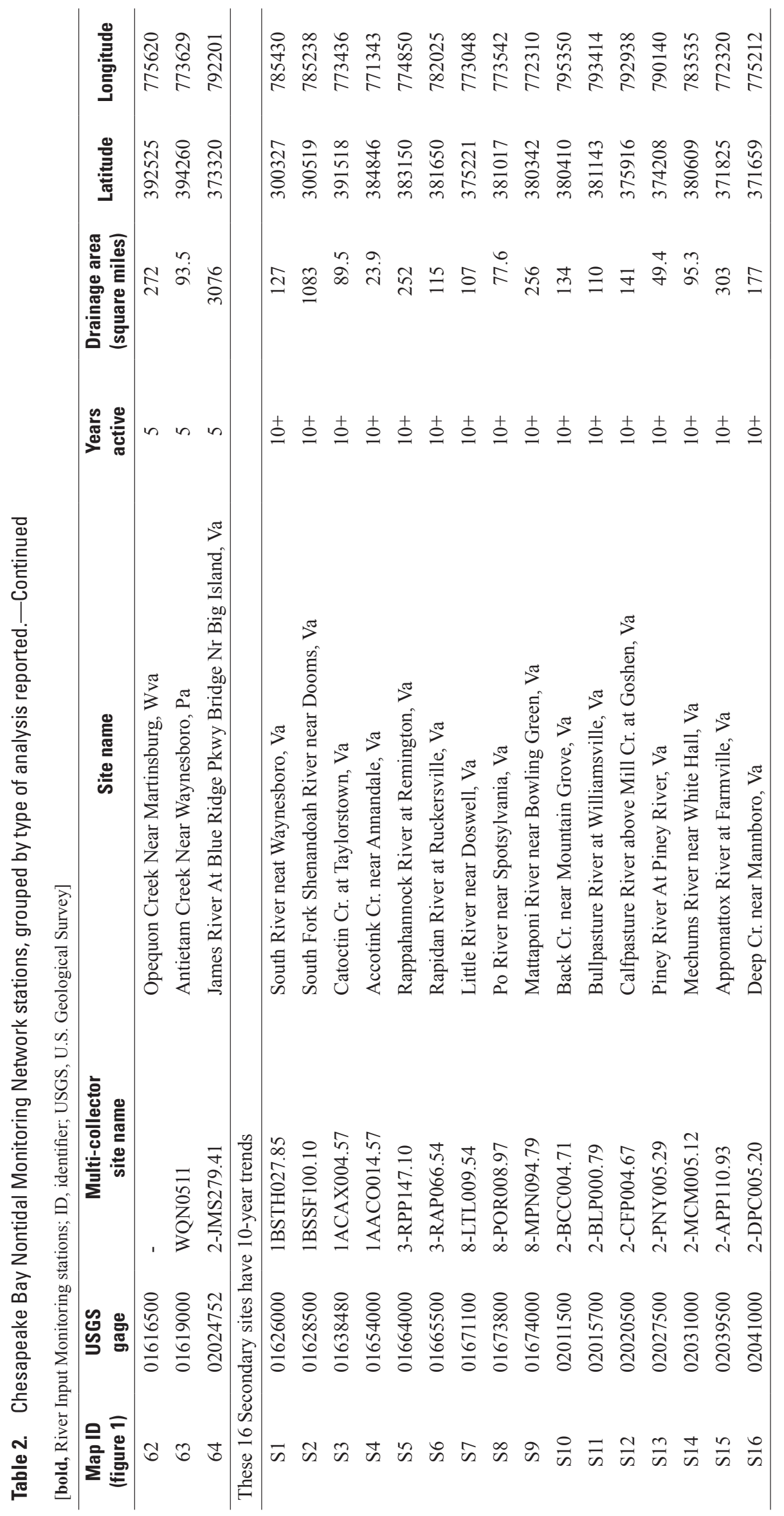


Table 3. Nitrogen, phosphorus, and sediment species tested for trend.

[N, nitrogen; mg/L, milligrams per liter $]$

\begin{tabular}{llll}
\hline \multicolumn{1}{c}{ Constituent } & \multicolumn{1}{c}{$\begin{array}{c}\text { Species } \\
\text { (parameter code) }\end{array}$} & Units & Abbreviation \\
\hline Nitrogen & Total nitrogen (00600) & $\mathrm{mg} / \mathrm{L}$ & $\mathrm{TN}$ \\
& $\begin{array}{l}\text { Total or dissolved nitrate, or, total or dissolved nitrite plus nitrate } \\
(00618,00620,00630, \text { or 00631) as N }\end{array}$ & $\mathrm{mg} / \mathrm{L}$ & $\mathrm{mg} / \mathrm{L}$ \\
Phosphorus & Total phosphorus $(00665)$ & $\mathrm{mg} / \mathrm{L}$ & $\mathrm{TP}$ \\
& Dissolved inorganic phosphorus $(00671)$ & $\mathrm{mg} / \mathrm{L}$ & $\mathrm{mg} / \mathrm{L}$ \\
Sediment & Suspended sediment $(80154)$ & $\mathrm{mg} / \mathrm{L}$ & TSS \\
\hline
\end{tabular}

suspended sediment (SSC) and total suspended solids (TSS) differ, concentrations of SSC tend to be higher, and measurements tend to be more accurate than those of TSS, particularly at higher flows (Kammerer and others, 1998) and where sediments are fine grained. Since February 2001, USGS policy has mandated the use of SSC rather than TSS analysis for suspended sediment. A recent (2006) enhancement to the data network (targeted collection of storm samples) is that the SSC analysis for sediment is used for samples collected at higher flows at many of the non-USGS sampling locations to improve comparisons with USGS data and provide more accurate estimates of sediment loads. Computing sediment loads at many non-USGS sites is nearly impossible as a result of the lack of SSC samples. Therefore, when data files were generated from the database, if sediment samples had been analyzed for both SSC and TSS, precedence was given to the SSC analysis value, and missing values were populated with TSS values. This procedure resulted in the combining of the two parameters into a single parameter named "SEDIMENT" (table 3).

To calculate trends, missing values were estimated. Many were calculated as the sum of reported analytes; for example, total nitrogen (TN) can be calculated as the sum of total dissolved and total particulate nitrogen. Missing values were estimated only for the input data files used to estimate trends and were not populated in the nontidal database. If the concentration of one or more of the nitrogen or phosphorus species used in calculating TN or total phosphorus (TP) was below the detection limit and greater than 5 percent of the summed total, then the remark code was coded as "less than" $(<)$.

As previously mentioned, the data analysis for loads and trends was performed on data from two time periods - the POR and 10 years-and loads were also calculated for the last 5 years (2006-10). Because the data for these time periods are subsets, master water-quality files were constructed from the nontidal database. Control files dictated to the program which time period to use. The longest period for reporting trend results for this study was October 1984 through September 2010. The shorter time-series data were used if they met certain criteria. For the 10-year period to be used, the database must include approximately 80 samples representing both monthly and storm samples. For the 5-year period to be used, the database must include 40 monthly and storm samples. The samples collected must represent the full range of the hydrograph during the estimation time period. Daily streamflow frequencies were developed for each site and the samplecollection times were plotted on a hydrograph to confirm that sampling occurred over the entire range of flows.

\section{Water-Quality Model}

Concentration data retrieved from the nontidal database were the basis for the load and trend test analyses in this study. Annual loads and flow-adjusted trends were calculated using the USGS water-quality model ESTIMATOR (Cohn and others, 1989, eq. 1) for all POR (long-term) and 10-year sites, and annual loads were calculated using ESTIMATOR for the 5-year sites.

\section{Load Estimation}

Water-quality models were developed to estimate loads and flow-adjusted trends in water quality. The models use multiple linear regressions to relate observed concentration to predictor variables of streamflow and time. Models were developed for 64 sites, for all species given in table 2, and for each of the three time periods of interest. A total of 640 models were developed. Diagnostic measures used to select the best regression model included residual non-normality, heteroscedasticity (nonconstancy of the variance of the residuals over the levels of the predictor variables), low coefficient of determination $\left(\mathrm{R}^{2}\right)$ values, and high model mean square errors. 
Model results that failed to meet the diagnostic measures were not reported. Estimates of constituent loading provide critical information on the amount and timing of material reaching downstream water bodies. A load is an integrated mass flux over some time interval $\left\{t_{a}, t_{b}\right\}$ :

$$
L=\int_{t a}^{t_{b}} l(t) d t=\int_{t a}^{t_{b}} k c(t) q(t) d t
$$

where

$$
\begin{aligned}
& L \quad \text { is the total load, } \\
& l \text { is the instantaneous load, } \\
& k \text { is a unit conversion factor, } \\
& c \quad \text { is the instantaneous observed concentration, } \\
& \text { and } \\
& q \quad \text { is the instantaneous streamflow. }
\end{aligned}
$$

The load represents the mass transported and delivered downstream from the point at which $\mathrm{c}$ and $\mathrm{q}$ are measured.

ESTIMATOR computes loads in two steps. First, a center-estimate linear model is fit to the logarithm of the concentration. The model corrects for bias from transforming logs back to "normal" space using the Minimum Variance Unbiased Estimator (MVUE) developed by Bradu and Mundlak (1970). The Adjusted Maximum Likelihood Estimator (AMLE) (Cohn, 1988) is used to estimate the log-linear model for sites having censored (below the detection limit) observations, and ordinary least squares is used for sites without censored data. AMLE is identical to ordinary least squares for the cases where no observations are censored. More detailed information on this procedure is included in Langland and others (2006).

A seven-coefficient parameter model is used to estimate loads for the Nontidal Program sites:

$$
\begin{aligned}
\ln (c) & =\hat{\beta}_{0}+\hat{\beta}_{1} \ln \left(q / q_{c}\right)+\hat{\beta}_{2}\left[\ln \left(q / q_{c}\right)\right]^{2}+\hat{\beta}_{3}\left(t-t_{c}\right) \\
+ & \hat{\beta}_{4}\left(t-t_{c}\right)^{2}+\hat{\beta}_{5} \sin (2 \pi t)+\hat{\beta}_{6} \cos (2 \pi t)+\varepsilon,
\end{aligned}
$$

where

$$
\begin{aligned}
& \text { In is the natural logarithm function; } \\
& c \text { is measured concentration, in milligrams per } \\
& \text { liter; } \\
& q \text { is measured daily mean streamflow, in cubic } \\
& \text { feet per second; } \\
& t \text { is time, in decimal years; } \\
& q_{c}, t_{c} \quad \text { are centering variables for streamflow and } \\
& \text { time; } \\
& \hat{\beta}_{i} \quad \text { are coefficients estimated by ordinary least } \\
& \text { squares (for noncensored observations) } \\
& \text { and AMLE (for censored observations); } \\
& \hat{\beta}_{0} \quad \text { is a constant; } \\
& \hat{\beta}_{1}, \hat{\beta}_{2} \quad \begin{array}{c}
\text { describe the relation between } \\
\text { concentration and streamflow; }
\end{array}
\end{aligned}
$$

$$
\begin{gathered}
\hat{\beta}_{3}, \hat{\beta}_{4} \quad \begin{array}{l}
\text { describe the relation between } \\
\text { concentration and time, indpendent } \\
\text { of flow; }
\end{array} \\
\hat{\beta}_{5}, \hat{\beta}_{6} \quad \begin{array}{r}
\text { describe seasonal variations in } \\
\text { concentration data; and }
\end{array} \\
\varepsilon \quad \begin{array}{l}
\text { is residual error, assumed to be normally } \\
\text { distributed with zero mean and } \\
\text { variance } o_{\varepsilon}^{2} .
\end{array}
\end{gathered}
$$

Centering variables are defined such that time and time squared (and streamflow and streamflow squared) predictor variables are independent, automatically accounting for any bias in the sampling strategy. The ideal sampling protocol that targets high- and low-flow conditions reduces the error in load estimates that results from the log-linear relation between concentration and flow.

Once model coefficients have been estimated, the second step in computing loads is to compute daily concentrations. Daily concentrations are used to estimate daily loads (and variances) using daily mean streamflow. Daily loads are summed to produce monthly and annual loads. The standard errors are estimated by using formulas in Gilroy and others (1990) and Cohn and others (1992).

Because the relation between concentration and streamflow can change over time as a result of changes in land use, wastewater discharges, best management practices, and climate change, a "moving-window" approach was developed to estimate loads for the nine RIM program sites (Yochum, 2000). The moving-window method optimizes load estimates near the middle of the estimation time period (year 5) by running 9-year "windows" with errors that generally increase with distance from the center. Where possible, loads are estimated at the beginning to try to center 1985 . Years 6 to 9 are considered provisional and will be updated in subsequent movingwindow years. The seven-parameter ESTIMATOR model with no moving window also is used to estimate long-term loads at the non-RIM sites. ESTIMATOR also is used for the 10- and 5-year time periods, beginning and ending with the relevant years.

\section{Trends in Water Quality}

Concentrations commonly are correlated with streamflow and season. Trends presented in this report (referred to as "flow-adjusted trends") were adjusted for streamflow and season to reduce the variability in concentrations and increase the likelihood of detecting an unbiased significant trend. These adjusted trends aid in the evaluation of changes in concentration resulting from changes in sources inputs and implementation of management practices. The relations between nutrient and sediment concentration and time (or discharge) are represented by both linear- and quadratic-term variables in the model form. A significant linear parameter indicates an upward $(+)$ or downward $(-)$ linear trend in nutrient and sediment concentrations. A significant quadratic parameter 
indicates a nonlinear relation between concentration and time (or discharge). For example, a significant positive quadratic parameter indicates a downward trend in early years followed by an upward trend in later years. A significant negative quadratic parameter indicates the opposite. If both the linearand quadratic-time trend parameters were significant, then an acceleration $(+)$ or deceleration $(-)$ in trend occurred in later years (see Langland and others (2006) for a detailed description). Similarly, a significant positive linear-flow parameter combined with a significant negative quadratic-flow parameter indicates that concentration would increase with increasing flow, but the rate of increase in concentration would decelerate, or decline, at higher flows. The entire time period (longterm, or 10-year) is used in a single ESTIMATOR model run to estimate flow-adjusted trends for all nutrients and sediments at all 33 sites.

\section{Changes in Streamflow}

Variability in streamflow is one of the primary factors affecting water quality in the Chesapeake Bay and its watershed. Variability in streamflow can be caused by both natural and human-influenced factors. The spatial and temporal patterns of precipitation; evapotranspiration; and recharge, storage, and discharge of groundwater are the primary natural factors affecting streamflow. Diversions, land-use changes, and other anthropogenic factors in the watershed also may affect streamflow. Variability in streamflow affects both the observed concentrations and the average loads and concentrations of nutrients and sediment delivered to the bay and tidal parts of rivers.

\section{Annual Mean Streamflow to Chesapeake Bay}

Estimated total freshwater flow entering the Chesapeake Bay in 2010 was 79,900 cubic feet per second $\left(\mathrm{ft}^{3} / \mathrm{s}\right), 2$ percent above the median for the period 1937 through 2010. Streamflow to the bay has been in the normal range (defined as the interquartile range, between the 25 th and 75 th percentiles) since 2005 , except in 2009 , when the total streamflow was below normal. The total streamflow entering the bay in 2010 was 20 percent greater than in 2009. From1937 through 2010, the 25th, 50th, and 75th percentiles of annual streamflow were $64,950,78,280$, and $89,000 \mathrm{ft}^{3} / \mathrm{s}$, respectively (fig. 2).

Upon examination of the streamflow record for 1937 to 2010, several decadal-scale patterns emerge. During 1937 to 1959 , annual total streamflow values were within the normal range 15 of the 23 years. A dry period occurred in the 1960s (streamflow during 5 of the 10 years was below the 25th percentile); however, wetter conditions occurred in the 1970s (streamflow during 5 of the 10 years was above the 75 th percentile). The long-term period used in this report (1985-2010) is of special interest in relating water-quality change to management actions and is the focus of this report. Annual streamflows were more variable during the last 20 years, with 6 of the 8 highest flows and 2 of the lowest flows occurring in this time period. The wetter conditions observed from 1970 to 2010 (when streamflows during 13 of 40 years were above the 75th percentile), combined with the effects of

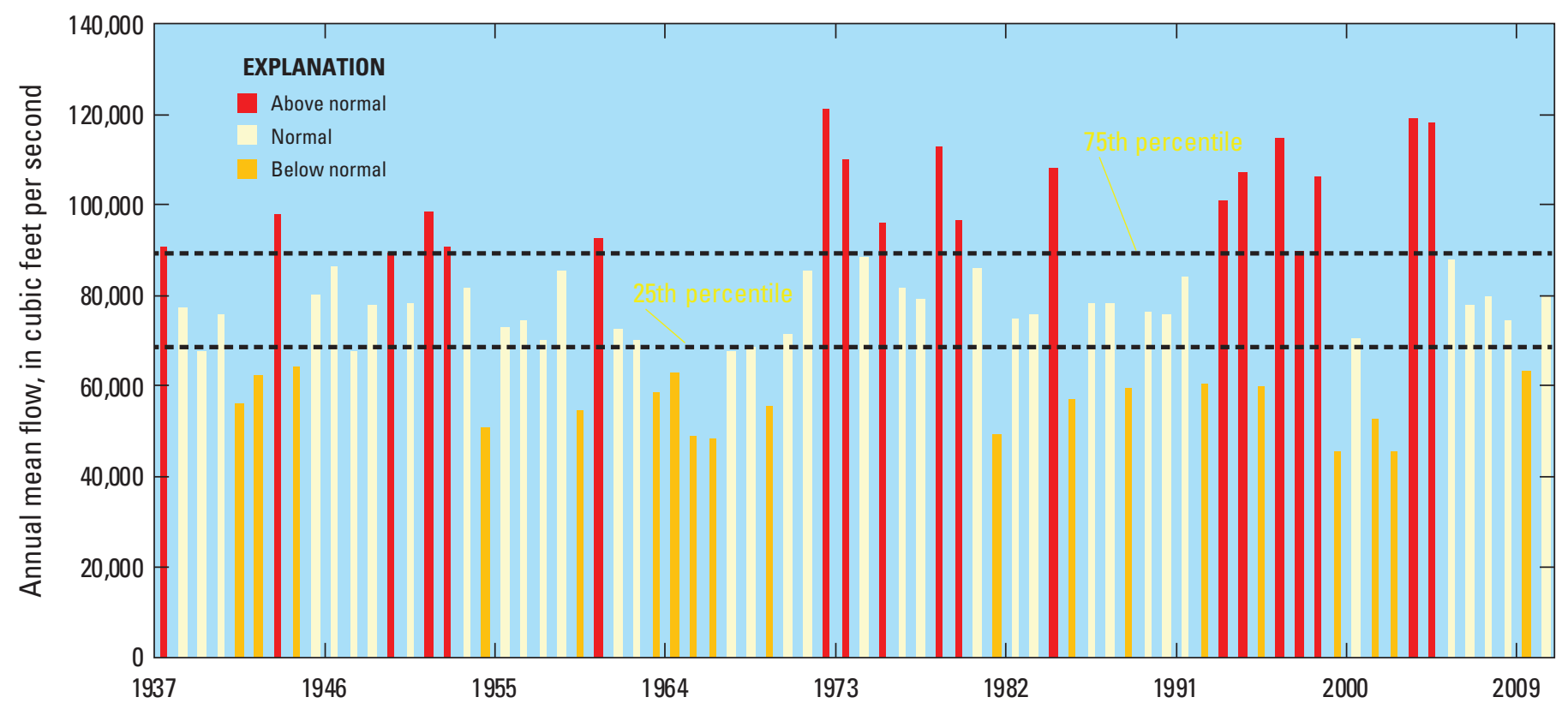

Figure 2. Estimated annual mean streamflow to Chesapeake Bay from 1937 to 2010. (Flow calculated using methods from Bue, 1968) 
increased nutrients and sediment from human activities reaching the bay, have been cited as possible causes for the declines in dissolved-oxygen concentration and water clarity in the bay that were documented in the 1970s and that persist (Phillips, 2002).

\section{Daily Mean Streamflow}

Regression models for daily mean streamflow at the 31 long-term sites were constructed using data from 1985 to 2010. The models included seasonal and 60-order autoregressive process terms.

Results from these models indicated that none of the 31 sites had significant trends in daily mean streamflow. Three sites in the northern Susquehanna River Basin (sites 1, 2, and 3 ; table 2) indicated a nonsignificant decline in daily streamflow of approximately 10 percent, whereas the remaining 28 sites indicated an increase in streamflow from 2009 to 2010, ranging from 10 to 75 percent. The median increase was approximately 40 percent. Daily mean streamflow at one site (site 31; table 2) increased from below to above normal. Daily and seasonal streamflows are illustrated on the Internet at http://md.water.usgs.gov/gis/trends/.

\section{Changes in Water Quality-Primary Sites}

Changes in streamflow, discussed in the previous section, affect streamwater quality. In this section, potential changes in water quality are discussed by comparing the constituent loads measured at the sites and flow-adjusted trends for the different modeled time periods.

\section{Load}

Nutrient and sediment loads have a substantial effect on the health of the Chesapeake Bay ecosystem and habitat in the rivers of the watershed. All but 3 of the 31 basins experienced an increase in runoff from 2009 to 2010. Nearly all sites had an increase in streamflow, constituent concentrations, and constituent loads. As a result, loads of all constituents at the nine RIM (farthest downstream) sites were higher in 2010 than in 2009. The loads at the RIM sites represent drainage from approximately 78 percent of the Chesapeake Bay watershed but do not include load estimates for the remaining 22 percent of the watershed, which for the most part represent the tidally influenced tributaries to the bay.

In 2010, combined estimated TN loads for the RIM sites were 178 million pounds (Mlbs), 27 Mlbs less than the long-term average of $205 \mathrm{Mlbs}$ for 1990 to 2010 (fig. 3), the common time period used for the RIM program. Combined estimated TN loads for the RIM program sites increased by nearly 50 Mlbs to 178 Mlbs (33 percent) from 2009 to 2010.

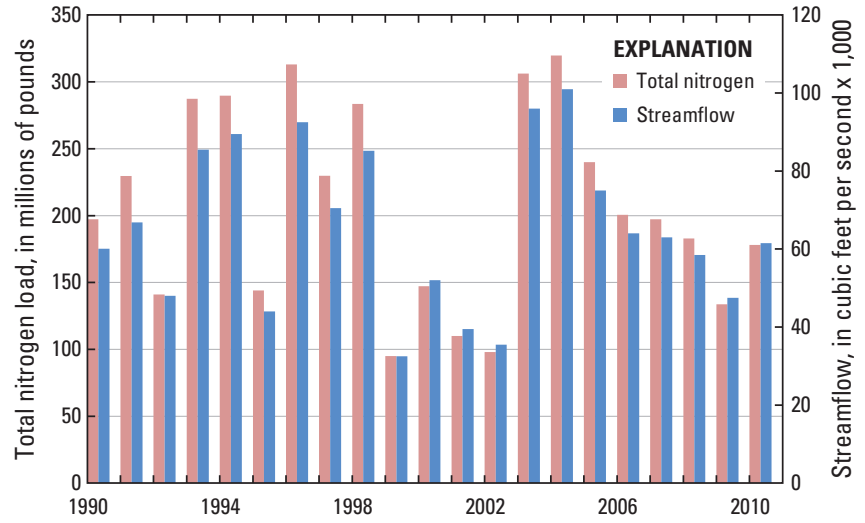

Figure 3. Annual combined total nitrogen loads and streamflow at the nine River Input Monitoring sites, Chesapeake Bay watershed, 1990-2010.

The high correspondence between annual streamflow and the TN combined load is apparent in figure 3 .

In 2010, the combined TP loads (13 Mlbs) exceeded the long-term average of $12 \mathrm{Mlbs}$ (fig. 4). The increase in streamflow and concentrations from 2009 to 2010 resulted in an estimated TP load increase of 7 Mlbs to 13 Mlbs, a 120-percent increase. Annual variability in the combined TP load is highly related to the variability in streamflow.

In 2010, the combined sediment load at the RIM sites, 15,500 Mlbs, was the third highest since 1990 and was far greater than the long-term average of 8,300 Mlbs (fig. 5). The increase in sediment loads from 2009 to 2010 was caused in large part by two major storm events during the spring season in the Potomac River Basin. The combined estimated sediment load increased by 12,000 Mlbs to 15,500 Mlbs, a 330-percent increase, from 2009 to 2010.

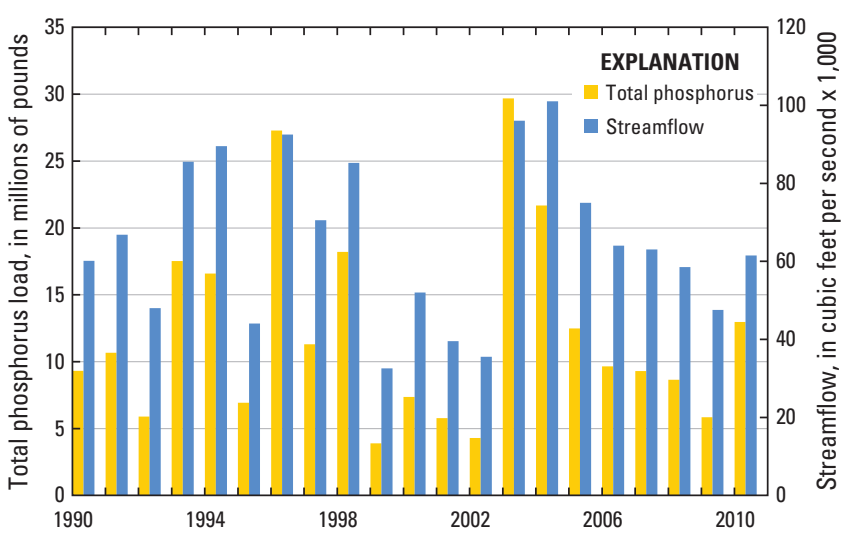

Figure 4. Annual combined total phosphorus loads and streamflow at the nine River Input Monitoring sites, Chesapeake Bay watershed, 1990-2010. 


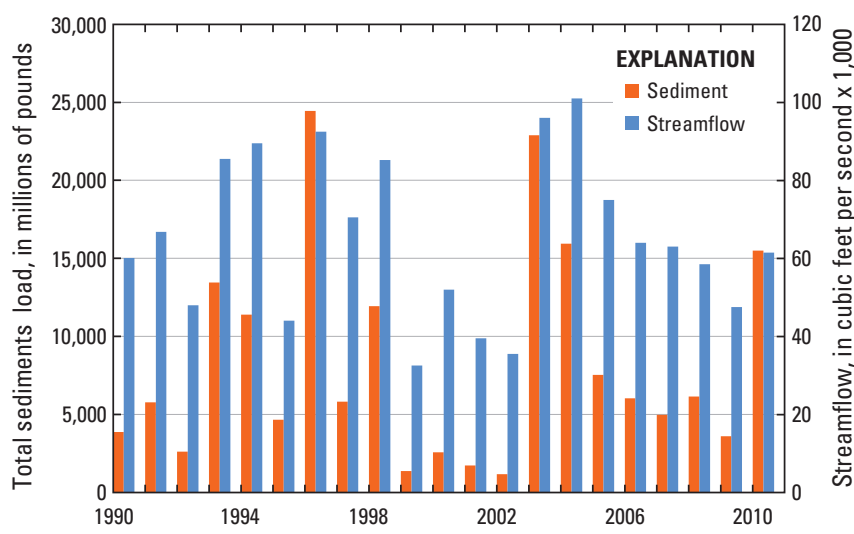

Figure 5. Annual combined total sediment loads and streamflow at the nine River Input Monitoring sites, Chesapeake Bay watershed, 1990-2010.

\section{Flow-Adjusted Trends}

Observed concentrations are highly influenced by variability in streamflow and season. The seven-parameter regression model indicated in equation 1 is used to estimate a trend independent of the influence of streamflow and season to improve the understanding of water-quality changes that may result from human influences. Model results are used to determine flow-adjusted trends by partitioning variability in observed concentration due to season and streamflow, so that the coefficients from the time parameters in equation 1 are estimates of the amount of change over time without interference from streamflow and seasonal influences.

The flow-adjusted trend does not necessarily represent all the water-quality changes that result from human activities and management actions; it describes only those changes unrelated to flow. For example, a change in farming practices that reduces surface runoff but increases ground-water recharge or a change in atmospheric deposition may not be captured in the flow-adjusted trend. Therefore, although flow-adjusted trends are an indicator of human activities that affect water quality within a watershed, the relative magnitude of the trend must be considered in terms of the hydrologic variability.

Flow-adjusted trends in TN, TP, and sediment are discussed by major watershed (nine RIM sites) and by total number of monitoring locations for the two time periods. Trends at the nine RIM sites for the period 1990-2010 are shown in table 4 . The trend results for the RIM sites are described because they are for the most part located on the largest tributaries to the bay and, therefore, represent overall trends for the basin. A common start date of 1990 is used for the nine RIM sites.

Total Nitrogen: The three largest monitored rivers (Susquehanna, Potomac, and James) and the Patuxent River exhibit statistically significant downward trends in TN (table 4). Only the Pamunkey and Choptank Rivers exhibit statistically significant upward trends in TN. The remaining RIM rivers (Rappahannock, Mattaponi, and Appomattox) indicate no significant trend.

In the 31-site network, 21 sites had improving trends, 2 sites had degrading trends, and 8 sites had no trend. Eight sites in the Susquehanna River Basin, including the RIM site, had decreasing trends in TN over the study period (fig. 6 and table 5). Of the 11 sites in the Potomac River Basin, 9 showed decreasing flow-adjusted trends in $\mathrm{TN}$, and 2 showed no statistically significant trend. Three sites in the lower Virginia basins indicated significantly decreasing flow-adjusted trends in $\mathrm{TN}$, one site showed an increasing trend, and three sites showed no statistically significant trend.

Total Phosphorus: With respect to TP, the Patuxent, Mattaponi, and James River RIM sites have statistically significant downward trends, whereas the Choptank, Pamunkey, and Appomattox River RIM sites have statistically significant upward trends (table 4). The two RIM sites on the Susquehanna and Potomac Rivers indicate a nonsignificant downward trend in TP.

In the nontidal monitoring network, flow-adjusted trends in TP decreased significantly at 22 of the 31 sites, increased significantly at 4 sites, and were not significant at 5 sites (fig. 7 and table 5). Decreasing trends were observed at seven of the eight sites in the Susquehanna River Basin. In the Potomac River Basin, eight sites showed decreasing trends, and two sites showed no statistically significant trend. In the James River Basin, two sites had a decreasing trend, and one site had no significant trend. In the entire Chesapeake Bay Basin, 14 sites had a downward flow-adjusted TP trend greater than 50 percent, whereas 1 site had an upward trend greater than 50 percent.

Sediment: Statistically significant downward trends in sediment load were observed for the Susquehanna, Potomac, Patuxent, and Choptank River RIM sites. Only the Pamunkey River RIM site indicated a statistically significant upward trend in sediment (table 4). The James, Rappahannock, Mattaponi, and Appomattox River RIM sites showed no trend.

Significant downward flow-adjusted trends in sediment load were calculated at 10 of the 31 sites, whereas upward trends were reported at 8 sites. Increases greater than 50 percent were estimated at 2 of the 10 downward-trend sites and 5 of the 7 upward-trend sites (fig. 8 and table 5). In the Susquehanna River Basin, downward trends were estimated for five sites. Results for the Potomac River Basin indicate an equal number of sites (two) with significant downward and upward trends, and no significantly detectable trend at six sites. In the lower Virginia river basins, there were no sites with downward trends, four sites with upward trends, and four sites with no detectable significant trend. In addition, five sites had downward sediment flow-adjusted trends in sediment load with decreases greater than 50 percent, whereas two sites had increasing trends with increases greater than 50 percent. 
Table 4. Flow-adjusted trends for the nine River Input Monitoring sites, Chesapeake Bay watershed, 1990-2010.

[STAID: U.S. Geological Survey gaging station number; Map ID, as appears in figure 1; TN, total nitrogen; TP, total phosphorus; TSS, total suspended solids; FA Trend: magnitude in percent, positive, improving trend, negative, degrading trend; Tau, association between two measured quantiles, values closer to zero indicate more independence; p-value, $<0.05$ used for significance testing; Significance: indicated direction of a significant trend or ns (not significant)]

\begin{tabular}{|c|c|c|c|c|c|c|c|}
\hline 1578310 & 8 & Susquehanna River at Conowingo, MD & $\mathrm{TN}$ & -25.5 & -0.2944 & $(<0.0001)$ & IMPROVING \\
\hline 1491000 & 9 & Choptank River near Greensboro, Md. & $\mathrm{TN}$ & 6.8 & 0.0662 & $(0.0333)$ & DEGRADING \\
\hline 1594440 & 13 & Patuxent River at Bowie, MD & $\mathrm{TN}$ & -57.2 & -0.8492 & $(<0.0001)$ & IMPROVING \\
\hline 1668000 & 24 & Rappahannock River near Fredericksburg, VA & $\mathrm{TN}$ & -9.8 & -0.1036 & $(0.1194)$ & ns \\
\hline 1673000 & 26 & Pamunkey River near Hanover, VA & TN & 18.8 & 0.1725 & $(<0.0001)$ & DEGRADING \\
\hline 1674500 & 27 & Mattaponi River near Beulahville, VA & $\mathrm{TN}$ & -1 & -0.0100 & $(0.7924)$ & ns \\
\hline 1578310 & 8 & Susquehanna River at Conowingo, MD & $\mathrm{TP}$ & -7.4 & -0.0773 & $(0.2561)$ & ns \\
\hline 1491000 & 9 & Choptank River near Greensboro, Md. & $\mathrm{TP}$ & 47.5 & 0.3889 & $(<0.0001)$ & DEGRADING \\
\hline 1594440 & 13 & Patuxent River at Bowie, MD & TP & -58.9 & -0.8886 & $(<0.0001)$ & IMPROVING \\
\hline 1646580 & 22 & Potomac River at Chain Bridge, MD & $\mathrm{TP}$ & -12.1 & -0.1293 & $(0.0741)$ & ns \\
\hline 1668000 & 24 & Rappahannock River near Fredericksburg, VA & $\mathrm{TP}$ & -11.5 & -0.1218 & $(0.2380)$ & ns \\
\hline 1673000 & 26 & Pamunkey River near Hanover, VA & $\mathrm{TP}$ & 99.4 & 0.6900 & $(<0.0001)$ & DEGRADING \\
\hline 1674500 & 27 & Mattaponi River near Beulahville, VA & $\mathrm{TP}$ & -11.9 & -0.1265 & $(0.0368)$ & IMPROVING \\
\hline 1594440 & 13 & Patuxent River at Bowie, MD & Sediment & -44.6 & -0.5913 & $(<0.0001)$ & IMPROVING \\
\hline 1646580 & 22 & Potomac River at Chain Bridge, MD & Sediment & -61.9 & -0.9650 & $(<0.0001)$ & IMPROVING \\
\hline 1668000 & 24 & Rappahannock River near Fredericksburg, Va & TSS & -2.7 & -0.0270 & $(0.8655)$ & ns \\
\hline 1673000 & 26 & Pamunkey River near Hanover, Va & TSS & 123.7 & 0.8050 & $(<0.0001)$ & DEGRADING \\
\hline 1674500 & 27 & Mattaponi River near Beulahville, Va & TSS & -2.4 & -0.0247 & $(0.8228)$ & ns \\
\hline 2037500 & 29 & James River near Richmond, Va & TSS & 43.9 & 0.3639 & $(0.0108)$ & DEGRADING \\
\hline 2041650 & 30 & Appomattox River at Matoaca, VA & Sediment & 14.5 & 0.1351 & $(0.1116)$ & ns \\
\hline
\end{tabular}




\section{EXPLANATION}

River basin

Susquehanna

Western Shore

Choptank

Patuxent

Potomac

Rappahannock

Mattaponi

Pamunkey

James

Appomattox

Chesapeake Bay

Chesapeake Bay watershed boundary

Stream

Trend

- Not significant

$\nabla$ Decreased 0-50 percent

$\rightarrow$ Decreased less than 50 percent

A Increased 0-50 percent

- Increased greater than 50 percent

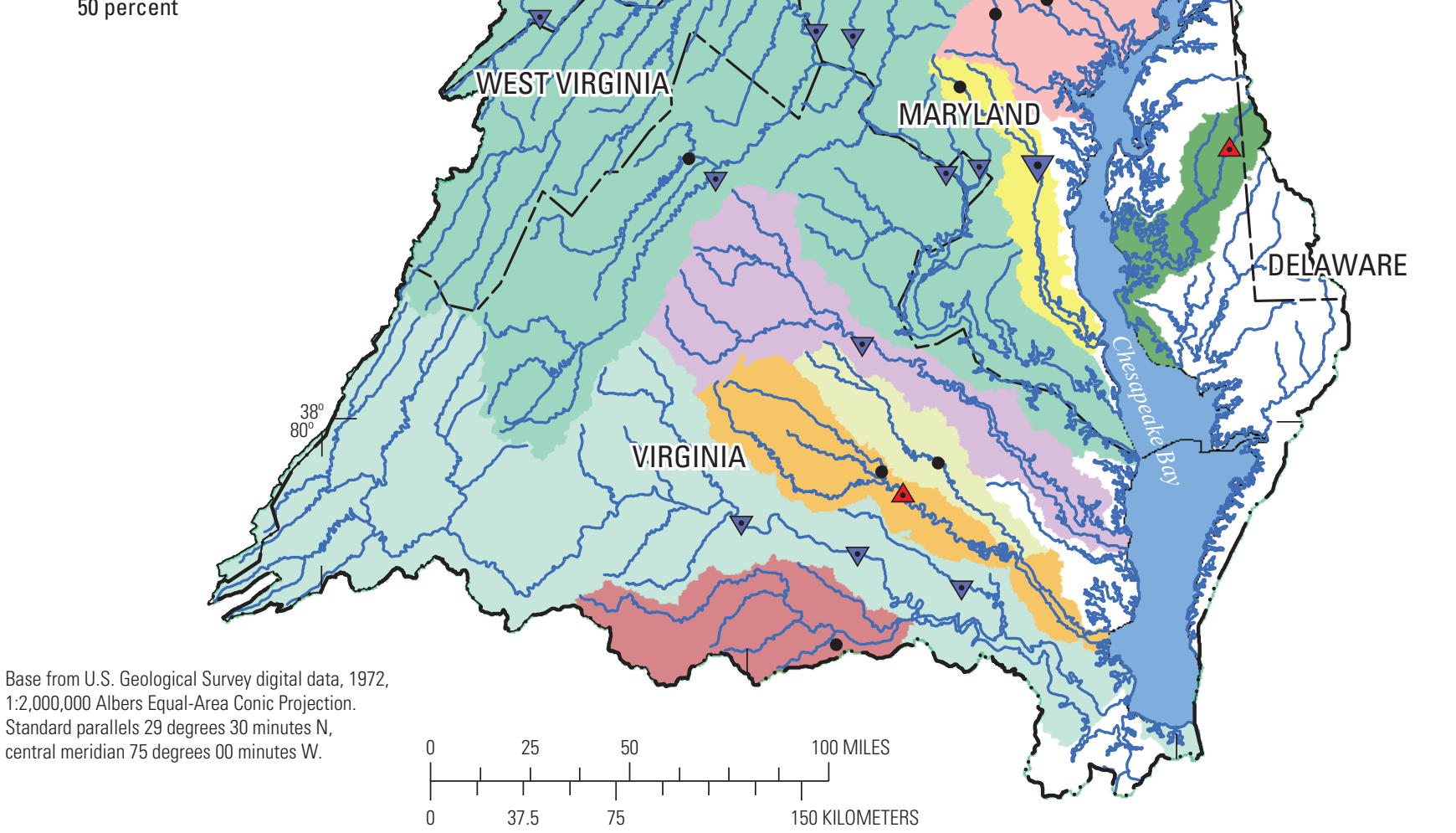

Figure 6. Flow-adjusted trends in total nitrogen concentration for 31 nontidal sites, 1985-2010. 


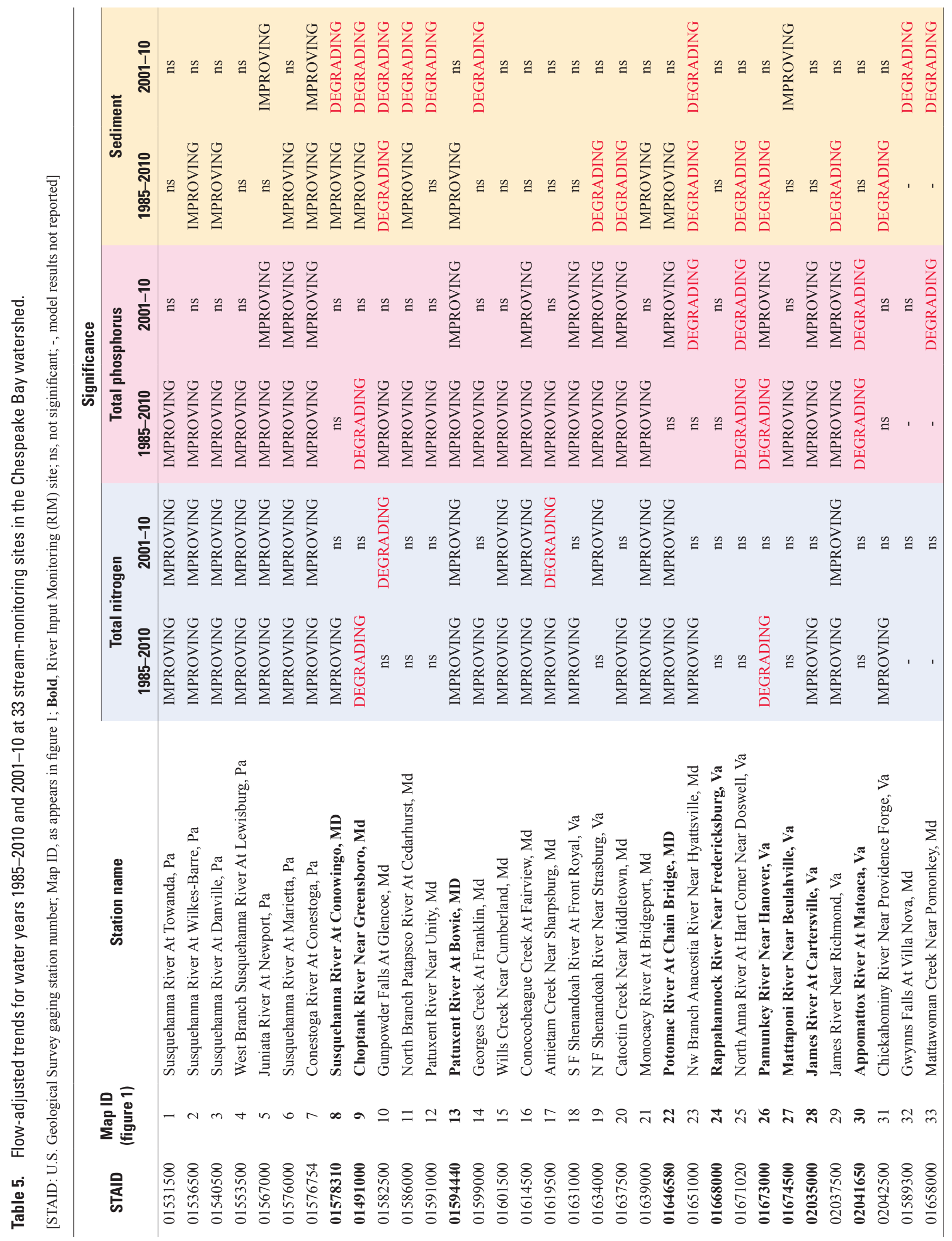




\section{EXPLANATION}

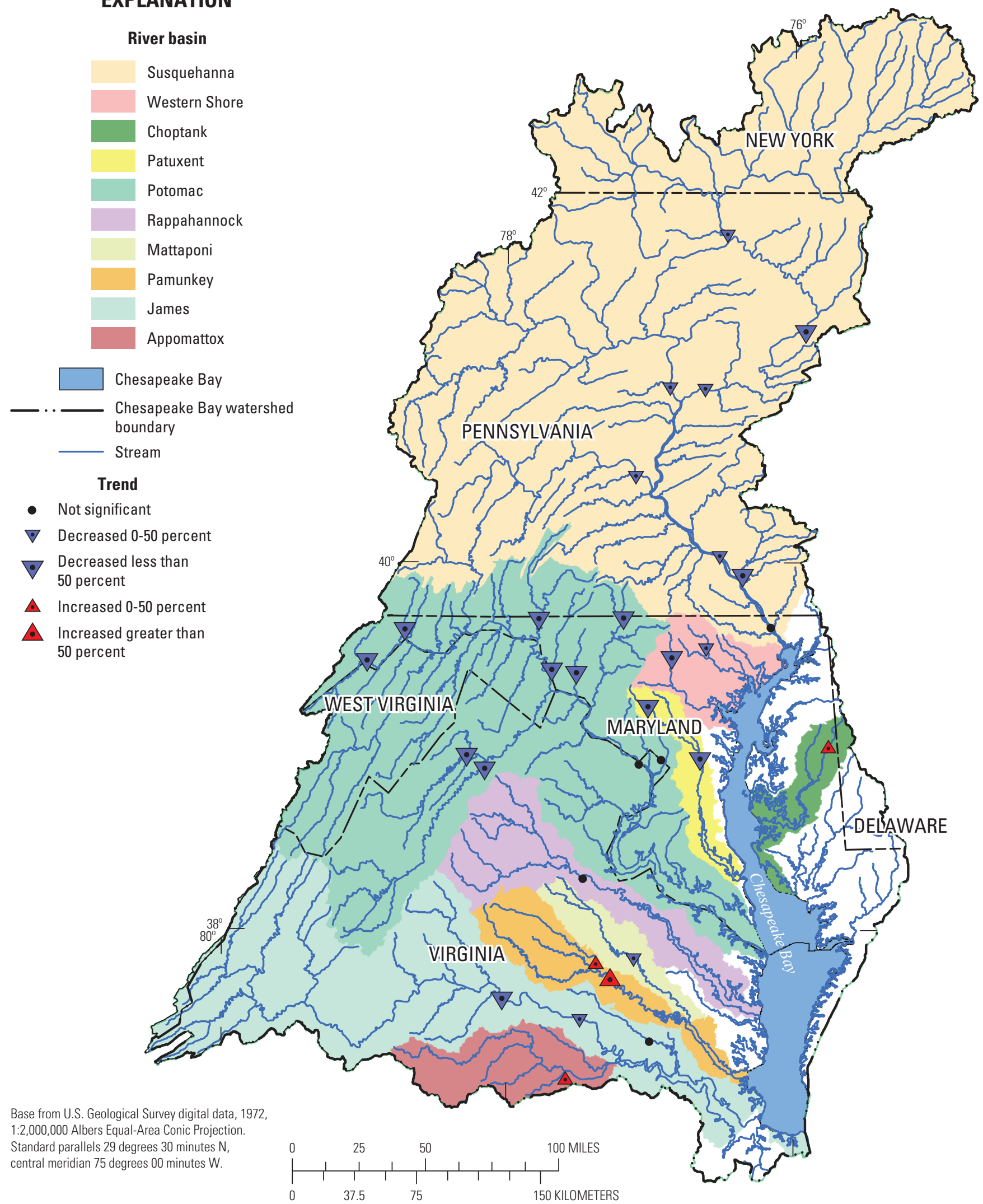

Figure 7. Flow-adjusted trends in total phosphorus concentration for 31 nontidal sites, 1985-2010. 


\section{EXPLANATION}

\section{River basin}

Susquehanna

Western Shore

Choptank

Patuxent

Potomac

Rappahannock

Mattaponi

Pamunkey

James

Appomattox

Chesapeake Bay

Chesapeake Bay watershed boundary

Stream

Trend

- Not significant

$\nabla$ Decreased 0-50 percent

- Decreased less than 50 percent

A Increased 0-50 percent

- Increased greater than 50 percent

Base from U.S. Geological Survey digital data, 1972,

1:2,000,000 Albers Equal-Area Conic Projection.

Standard parallels 29 degrees 30 minutes $\mathrm{N}$.

central meridian 75 degrees 00 minutes $W$.
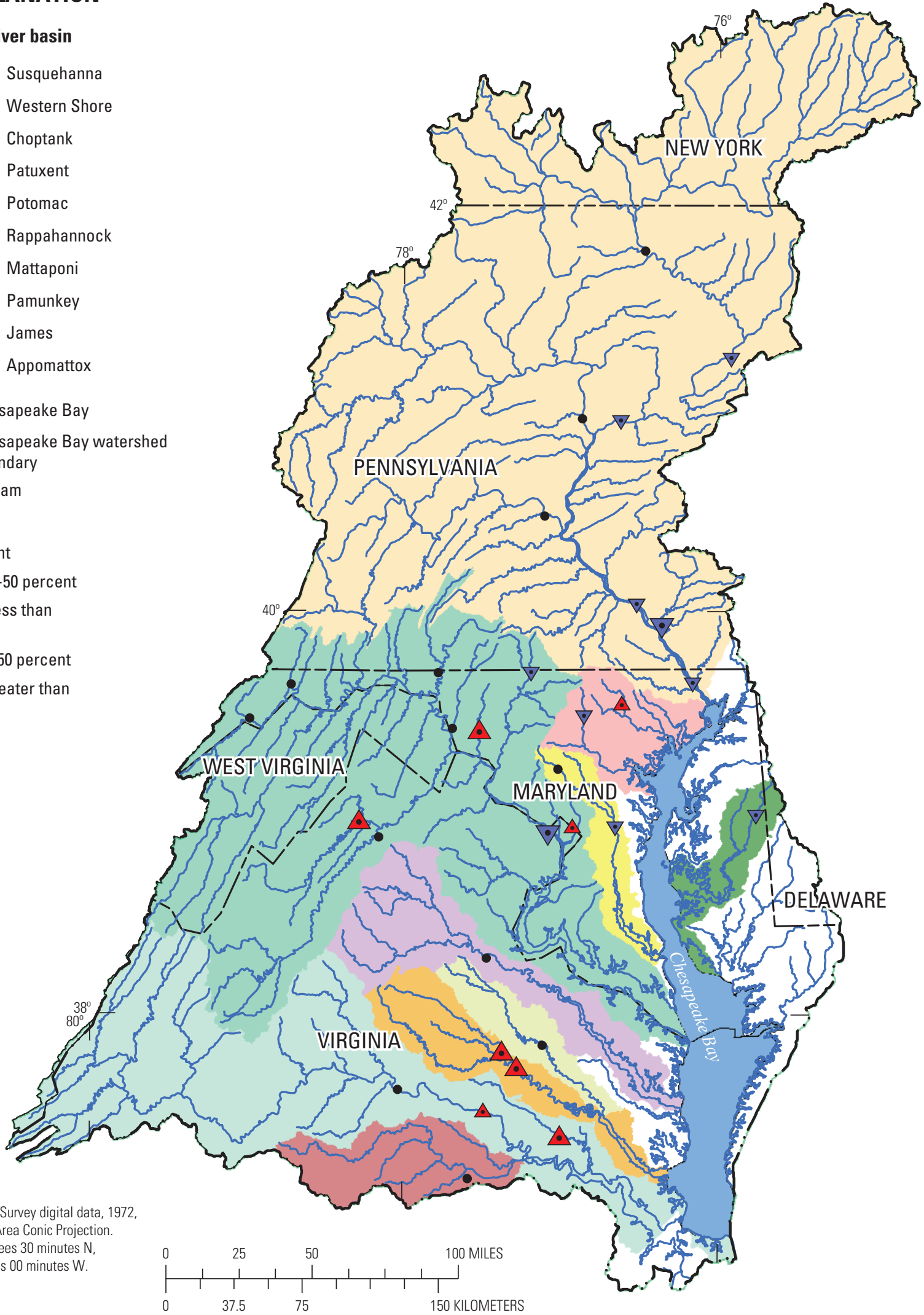


\section{Indicator Development}

The USGS worked with CBP partners to develop additional indicators (trend, yield, and combined) that graphically summarize water-quality data that will be placed in a Web-accessible format for use by the public. The indicators presented in this report are distinct from previous waterquality trends and loads summarized in that they (1) focus on recent (2001-10) data, (2) include data from a larger number of monitoring sites, and (3) use consistent periods of record. These indicators will assist water-quality managers in optimizing management actions to help meet TMDL.

\section{Trend Indicator}

Trends in concentrations were estimated using the load model ESTIMATOR. The USGS typically reports trends over the longest time period for which data are available. As discussed in this report, an additional 10-year time period was analyzed to examine changes in concentrations and loads over a shorter time frame. Trends in concentration were estimated for the period 2001-10 for 33 sites. Both flow and water-quality data are available for the 33 sites for the 10 -year minimum time period and the data represent samples collected over the entire range of flow conditions that occurred at all 33 sites during the 10 -year period.

Trend results for the two time periods (1985-2010 and 2001-10) are presented in table 5. A comparison of the number of significant trends during the two time periods indicates that (1) fewer sites showed significantly improving (downward) trends in the 10-year period for all constituents and (2) the sites with significantly degrading (upward) trends in the two time periods seldom coincided. Although fewer trends were found in the 10 -year time period than in the longer time period, sites with improving trends outnumbered sites with degrading trends in both time periods. Also, 10 of the 13 degrading trends in 1985-2010 became either not significant or improving during 2001-10, and 4 of the 15 degrading trends during the 2001-10 time period represent reversals from improving trends during 1985-2010. These changes in significant trends between the two time periods may be related to the rate of implementation and number of best management practices (BMPs) instituted, and the delay in improvement (lag time) from the actual detection of the improvement in water quality.

\section{Yield Indicator}

Yield is the load for a given time period divided by (normalized to) the drainage area (in square miles in this report). The yield indicator provides additional information about loads so that comparisons among sites can be made over a common time period. Annual loads at all 64 sites for 2006-2010 were estimated and converted to yields. The 5-year mean was used to represent the yield indicator. The mean yields at the 64 sites were sorted by magnitude, grouped into thirds (low, 1-22; medium, 23-43; and high, 44-64), color coded for display purposes, and resorted in the order in which they are listed in table 1 (table 6). Ranges for TN yields (in tons per square mile (tons $\left./ \mathrm{mi}^{2}\right)$ ) are low (0.83-1.39), medium (1.4-2.5), and high (2.0-10); ranges for TP yields are low (0.02-0.09), medium (0.10-0.18), and high (0.19-0.56); and ranges for sediment yields are low (12-58), medium (64-152), and high (160-2,500).

\section{Combined Indicator}

A new indicator, referred to in this report as the "combined indicator," was developed for this study. The combined indicator permits site-to-site comparisons of yields and trends. Trend results are available for 33 sites in the bay watershed for the most recent 10 years of record (2001-10), and yield results are available for 64 sites for the most recent 5 years of record (2006-10). After an evaluation of the data with the goal of efficiently displaying results from as many nontidal monitoring sites as possible, four classifications of the 10 -year trends were combined with three magnitude groupings of the 5-year yields to produce a classification system consisting of 12 categories (table 7). Relative yield (indicated by color) and trend direction (indicated by arrows) are shown in figures 6 to 8. By combining information about trend and yield in one illustration, these maps show that progress has been made in response to recent efforts to reduce inputs of nutrients and sediment to the bay from the watershed.

The combined trends and yields indicator for $\mathrm{TN}$ for the 64 sites is grouped by flow-adjusted-concentration trend direction (table 5) and yield (table 6) for the 64 sites in figure 9. Seventeen of the $33 \mathrm{TN}$ sites for which trends are available indicate improving (downward) trends; nearly half of these are in the Susquehanna River Basin (fig. 9). Two sites indicate degrading (upward) trends. More than half (16) of the sites had no significant trend. Yields generally decrease from north to south, and are higher in the northern areas of the bay basin (Susquehanna River), intermediate (medium) in the middle bay basin (Potomac River), and lower in the southern bay basin (Virginia rivers). One-third of the sites indicate improving trends and low to medium yields, but two sites indicate degrading trends and high yields. In addition, lower yields upstream appear to increase downstream in the Susquehanna River Basin.

The combined indicator for TP shows improving trends at 12 of the 33 sites for which trend data are available (table 6, fig. 10); however, 4 sites indicate degrading trends. Fewer than half the sites indicate no change. No general spatial pattern can be observed in yields of TP, with the exception of lower yields in the western headwaters of the Potomac River Basin (Maryland and West Virginia). High and medium yields appear in every major basin in the monitoring network. Results for TP are similar to those for TN; one-third of the sites indicate 
Table 6. Mean yields of nitrogen, phosphorus, and sediment at 64 stream-monitoring sites in the Chesapeake Bay watershed, 2006-10.

[blue, lower yields; green, medium yields; orange, higher yields; yields in tons per square mile; Map ID, as appears in figure 1]

\begin{tabular}{|c|c|c|c|c|c|c|c|c|c|}
\hline $\begin{array}{c}\text { Map ID } \\
\text { (figure 1) }\end{array}$ & $\begin{array}{c}\text { Site } \\
\text { number }\end{array}$ & $\begin{array}{c}\text { Total } \\
\text { nitrogen } \\
\text { yield }\end{array}$ & $\begin{array}{c}\text { Total } \\
\text { phosphorus } \\
\text { yield }\end{array}$ & $\begin{array}{l}\text { Sediment } \\
\text { yield }\end{array}$ & $\begin{array}{c}\text { Map ID } \\
\text { (figure 1) }\end{array}$ & $\begin{array}{c}\text { Site } \\
\text { number }\end{array}$ & $\begin{array}{l}\text { Total } \\
\text { nitrogen } \\
\text { yield }\end{array}$ & $\begin{array}{c}\text { Total } \\
\text { phosphorus } \\
\text { yield }\end{array}$ & $\begin{array}{l}\text { Sediment } \\
\text { yield }\end{array}$ \\
\hline 2 & 01536500 & 1.38 & 0.18 & 167.88 & 34 & 01515000 & 2.05 & 0.23 & 267.32 \\
\hline 5 & 01567000 & 1.99 & 0.08 & 46.78 & 37 & 01562000 & 2.04 & 0.06 & 72.18 \\
\hline 6 & 01576000 & 2.03 & 0.11 & 96.93 & 38 & 01568000 & 3.71 & 0.15 & 98.08 \\
\hline 7 & 01576754 & 9.58 & 0.39 & 160.46 & 39 & 01570000 & 4.91 & 0.08 & 64.76 \\
\hline 10 & 01582500 & 3.19 & 0.05 & 58.07 & 42 & 01574000 & 3.62 & 0.27 & 116.67 \\
\hline 11 & 01586000 & 4.37 & 0.12 & 130.14 & 43 & 01576787 & 10.01 & 0.57 & 394.70 \\
\hline 12 & 01591000 & 3.10 & 0.34 & 2549.53 & 44 & 01667500 & 1.32 & 0.36 & 426.90 \\
\hline 13 & 01594440 & 1.83 & 0.16 & 89.35 & 45 & 01487000 & 8.28 & 0.11 & 13.98 \\
\hline 14 & 01599000 & 1.62 & 0.09 & 71.29 & 46 & 01488500 & 4.44 & 0.25 & 39.43 \\
\hline 15 & 01601500 & 1.72 & 0.10 & 120.08 & 47 & 01491500 & 4.53 & 0.17 & 20.69 \\
\hline 16 & 01614500 & 4.84 & 0.13 & 82.56 & 48 & 01495000 & 5.50 & 0.41 & 653.29 \\
\hline 22 & 01646580 & 1.75 & 0.12 & 152.86 & 54 & 01580520 & 4.99 & 0.29 & 400.16 \\
\hline 23 & 01651000 & 2.54 & 0.54 & 288.40 & 55 & 01594526 & 1.43 & 0.48 & 1229.73 \\
\hline 24 & 01668000 & 1.07 & 0.25 & 353.41 & 56 & 01604500 & 0.69 & 0.04 & 33.49 \\
\hline 25 & 01671020 & 0.39 & 0.04 & 40.87 & 57 & 01608500 & 0.81 & 0.07 & 52.70 \\
\hline 26 & 01673000 & 0.54 & 0.07 & 42.38 & 58 & 01610155 & 1.05 & 0.02 & 47.50 \\
\hline 27 & 01674500 & 0.52 & 0.05 & 12.10 & 59 & 01611500 & 0.72 & 0.04 & 35.37 \\
\hline 28 & 02035000 & 0.66 & 0.14 & 125.90 & 60 & 01613095 & 1.43 & 0.05 & 81.62 \\
\hline 29 & 02037500 & 0.70 & 0.18 & 204.58 & 61 & 01613525 & 1.58 & 0.06 & 90.56 \\
\hline 30 & 02041650 & 0.48 & 0.05 & 13.78 & 62 & 01616500 & 2.04 & 0.18 & 57.71 \\
\hline 31 & 02042500 & 0.69 & 0.13 & 37.01 & 63 & 01619000 & 4.49 & 0.17 & 55.31 \\
\hline 32 & 01589300 & 2.17 & 0.35 & 491.43 & 64 & 02024752 & 0.58 & 0.10 & 97.45 \\
\hline
\end{tabular}


Table 7. Combined trend and yield indicator counts by classification for the 64 sites in the Chesapeake Bay watershed.

[Ten-year flow-adjusted trends are for 33 sites, and 5-year mean yields are for all 64 sites]

\begin{tabular}{|c|c|c|c|c|c|}
\hline \multirow[b]{2}{*}{ Total nitrogen } & & \multicolumn{4}{|c|}{ 10-year flow-adjusted trend (2001-10) } \\
\hline & & Degrading (upward) & Not significant & Improving (downward) & Trends not available \\
\hline \multirow{2}{*}{$\begin{array}{l}\text { 5-year yields } \\
(2005-10)\end{array}$} & Medium & 0 & 6 & 7 & 10 \\
\hline & Low & 0 & 4 & 8 & 8 \\
\hline \multirow{3}{*}{$\begin{array}{l}\text { 5-year yields } \\
(2005-10)\end{array}$} & High & 2 & 2 & 6 & 14 \\
\hline & Medium & 1 & 7 & 5 & 7 \\
\hline & Low & 1 & 3 & 6 & 10 \\
\hline Total Sediment & & Degrading (upward) & Not significant & Improving (downward) & Trends not available \\
\hline $\begin{array}{l}\text { 5-year yields } \\
(2005-10)\end{array}$ & Low & 3 & 5 & 2 & 13 \\
\hline
\end{tabular}

improving trends and low to medium yields, whereas three sites indicate degrading trends and high yields.

For sediment, unlike TN and TP, more sites indicate degrading trends (9) than improving trends (3) (table 6; fig. 11). Seven of the nine sites with degrading trends in sediment are in the Potomac River Basin, whereas two of the three improving sites are in the Susquehanna River Basin. Like yields of TP, sediment yields show no discernible spatial pattern. In contrast to TN and TP sites, more sediment sites indicate degrading water quality and high yield (5) than improving water quality and low yield (2).

A degrading water-quality trend and a high yield at a site might be considered the "least favorable" combination in table 7 . In contrast, an improving water-quality trend and a low yield might be considered the "most favorable" combination, and the goal for all sites. Of the 33 sites, 2, 2, and 5 sites would be classified as "least favorable" (27 percent) and 8,6 , and 2 sites would be classified as "most favorable" (46 percent) for TN, TP, and sediment, respectively. If managers and scientists wanted to consider sites near the middle of the range (improving or not-significant trends and medium yields) for economic or environmental feasibility reasons, then 13,12, and 10 sites could be classified as "near middle" (35 percent) for TN, TP, and sediment, respectively. For nutrients and sediment, "more favorable" areas generally are located in parts of the upper and western Susquehanna and western Potomac River Basins and many locations in Virginia. "Least favorable" areas tend to be located in the middle of the Chesapeake Bay Basin. Locations classified as "most favorable" tend to be dominated by forested land, whereas those classified as "least favorable" tend to be dominated by urban and agricultural land uses.

\section{Changes in Water Quality-Secondary Sites}

As mentioned previously, the Chesapeake Bay Nontidal Monitoring Network was designed for a variety of sampling and study needs. Primary sites are sampled monthly with targeted stormflow sampling, and secondary sites are sampled monthly but with no targeted stormflow sampling, by using the protocols established by the monitoring network partners and multiple Federal, State, and basin commissions (U.S. Environmental Protection Agency, 2004.

The secondary network currently consists of 16 sites, all located in Virginia (table 8 and fig. 1). Ten-year trends (2001-10) were estimated at each site for TN, TP, and sediment. Not all results are reported as a result of a lack of data to calibrate the ESTIMATOR model or inadequate sample coverage over the hydrograph. Four of the 16 sites indicated improving trends for TN, and 2 of the 14 sites indicated improving trends for TP. A degrading trend for sediment was found at one site.

\section{Future Directions}

The annual evaluation of water-quality trends in the Chesapeake Bay watershed has been done with USGS participation since the early 1990s. Trends from the River Input Monitoring (RIM) sites were originally reported by USGS using multivariate regression techniques (ESTIMATOR model) developed by Cohn and others (1992) and by 2010 


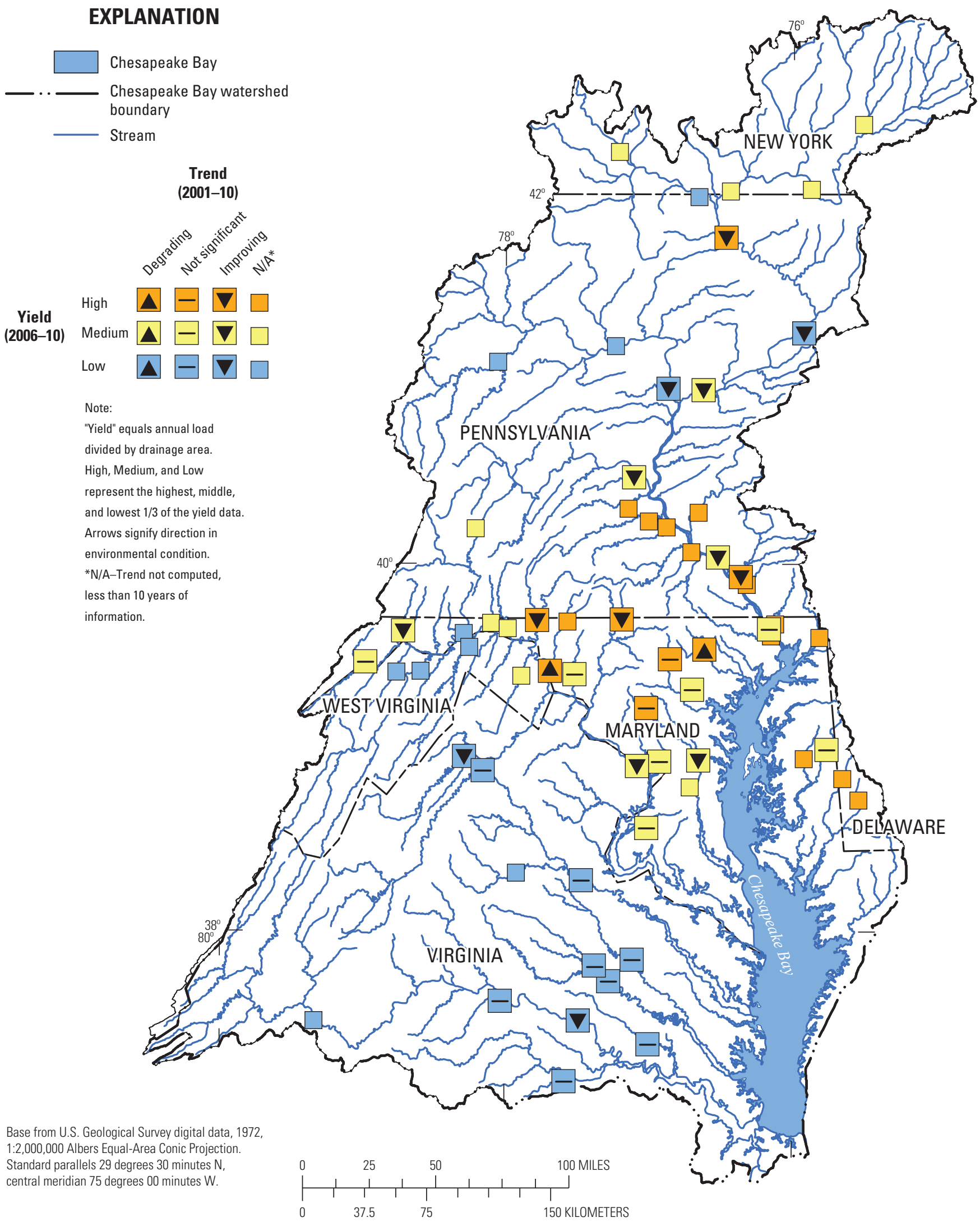

Figure 9. Combined nitrogen trends (WY2001-10) and yields (WY2006-10) at 64 stream monitoring sites in the Chesapeake Bay watershed. (WY, water years - the 12-month period from October 1 to September 30, designated by the year in which it ends) 


\section{EXPLANATION}

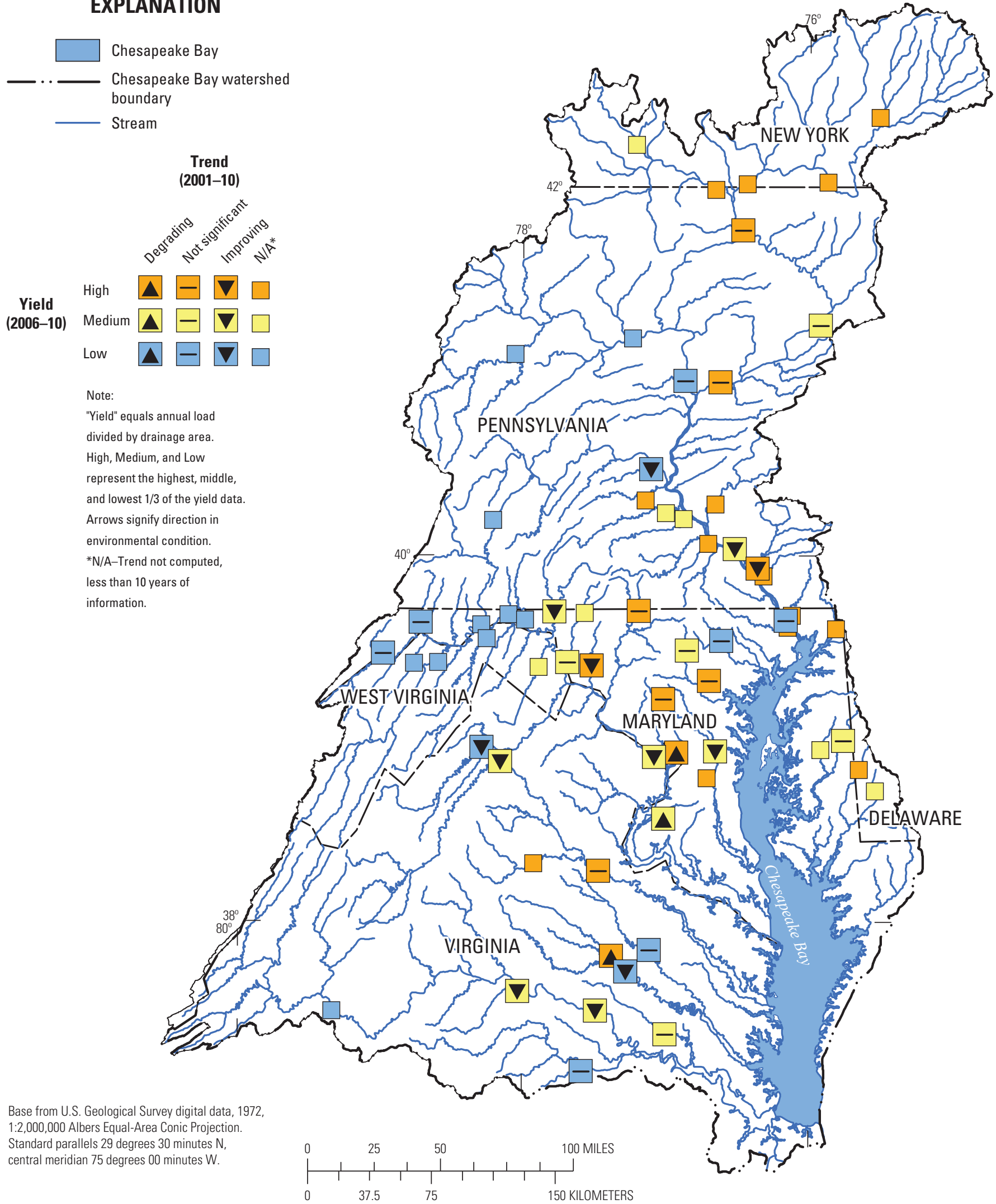

Figure 10. Combined phosphorus trends (WY2001-10) and yields (WY2006-10) at 64 stream monitoring sites in the Chesapeake Bay watershed. (WY, water years - the 12-month period from October 1 to September 30, designated by the year in which it ends) 


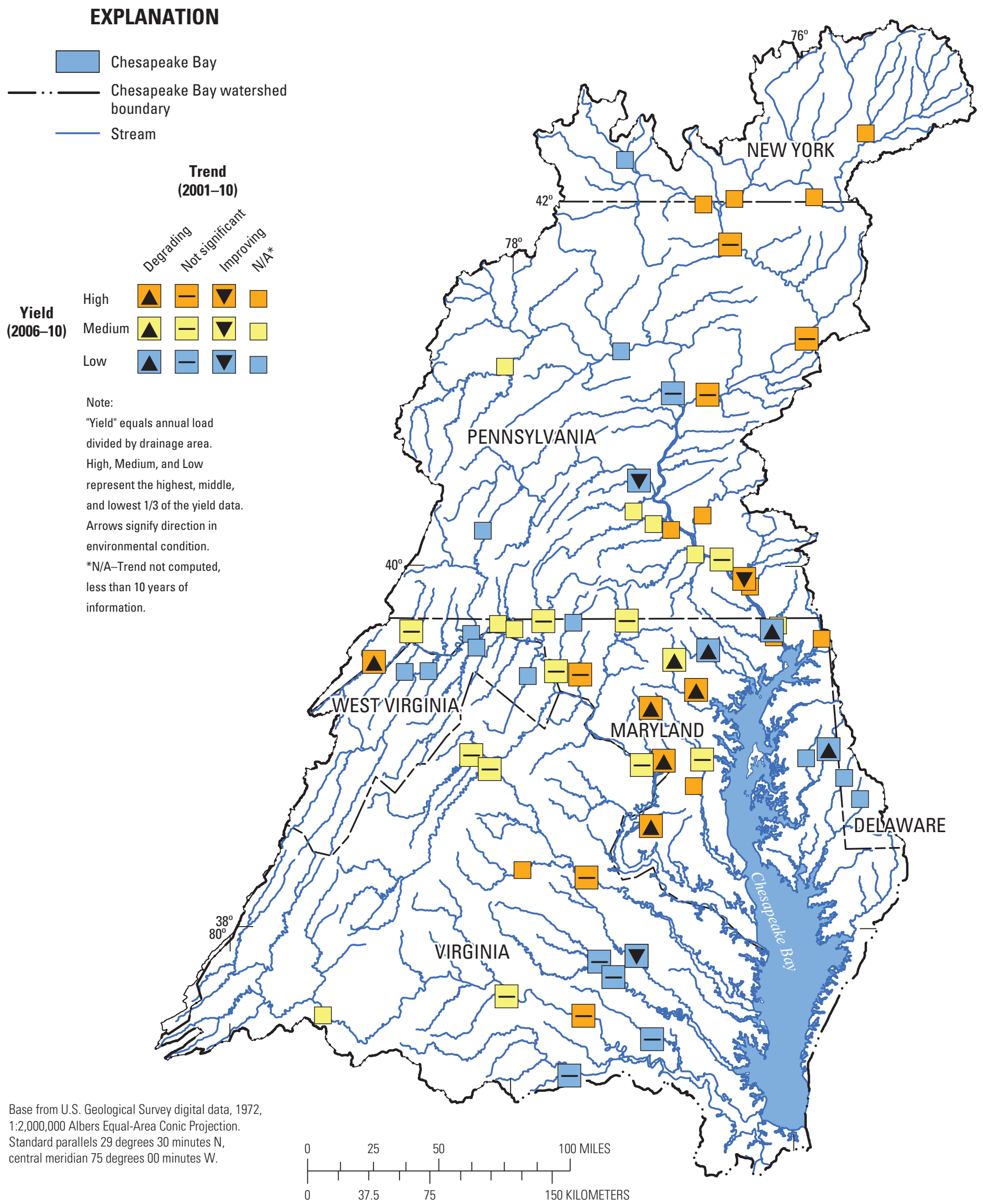

Figure 11. Combined sediment trends (WY2001-10) and yields (WY2006-10) at 64 stream monitoring sites in the Chesapeake Bay watershed. (WY, water years - the 12-month period from October 1 to September 30, designated by the year in which it ends) 
Table 8. Trend results for the 16 Virginia secondary sites in the Chesapeake Bay Nontidal Monitoring Program.

[STAID: U.S. Geological Survey gaging station number; Map ID, identification number that appears in figure 1; TN, total nitrogen; TP, total phosphorus; FA Trend: magnitude in percent, positive, improving trend, negative, degrading trend; Significance: type of significant trend or ns (not significant)]

\begin{tabular}{|c|c|c|c|c|c|}
\hline STAID & Map ID & Station name & Constituent & FA Trend & Significance \\
\hline 1626000 & S1 & SOUTH RIVER NEAR WAYNESBORO, VA & TN & -14.5 & ns \\
\hline 1628500 & S2 & S.F. SHENANDOAH RIVER NEAR LYNNWOOD, VA & $\mathrm{TN}$ & -6.5 & $\mathrm{~ns}$ \\
\hline 1638480 & S3 & CATOCTIN CREEK NEAR TAYLORSTOWN, VA & $\mathrm{TN}$ & -9.1 & ns \\
\hline 1654000 & S4 & ACCOTINK CREEK NEAR ANNANDALE, VA & $\mathrm{TN}$ & -46.9 & IMPROVING \\
\hline 1664000 & S5 & RAPPAHANNOCK RIVER AT REMINGTON, VA & $\mathrm{TN}$ & -0.5 & ns \\
\hline 1665500 & S6 & RAPIDAN RIVER AT RUCKERSVILLE, VA & $\mathrm{TN}$ & -52.8 & IMPROVING \\
\hline 1671100 & S7 & LITTLE RIVER NEAR DOSWELL, VA & $\mathrm{TN}$ & -22.7 & $\mathrm{~ns}$ \\
\hline 1673800 & S8 & PO RIVER NEAR SPOTSYLVANIA, VA & $\mathrm{TN}$ & -30 & IMPROVING \\
\hline 1674000 & S9 & MATTAPONI RIVER NEAR BOWLING GREEN, VA & $\mathrm{TN}$ & -42 & IMPROVING \\
\hline 2011500 & S10 & BACK CREEK NEAR MOUNTAIN GROVE, VA & $\mathrm{TN}$ & -13.9 & ns \\
\hline 2015700 & S11 & BULLPASTURE RIVER AT WILLIAMSVILLE, VA & $\mathrm{TN}$ & -11.2 & ns \\
\hline 2020500 & $\mathrm{~S} 12$ & CALFPASTURE RIVER ABV MILL CREEK AT GOSHEN, VA & $\mathrm{TN}$ & -12.8 & ns \\
\hline 2027500 & S13 & PINEY RIVER AT PINEY RIVER, VA & $\mathrm{TN}$ & -18.6 & ns \\
\hline 2031000 & S14 & MECHUMS RIVER NEAR WHITE HALL, VA & $\mathrm{TN}$ & -15.4 & ns \\
\hline 2039500 & S15 & APPOMATTOX RIVER AT FARMVILLE, VA & $\mathrm{TN}$ & -19.9 & ns \\
\hline 2041000 & S16 & DEEP CREEK NEAR MANNBORO, VA & $\mathrm{TN}$ & -6.8 & ns \\
\hline 1626000 & S1 & SOUTH RIVER NEAR WAYNESBORO, VA & TP & -25.7 & IMPROVING \\
\hline 1628500 & S2 & S.F. SHENANDOAH RIVER NEAR LYNNWOOD, VA & TP & -28.8 & ns \\
\hline 1638480 & S3 & CATOCTIN CREEK NEAR TAYLORSTOWN, VA & TP & 20.1 & ns \\
\hline 1654000 & S4 & ACCOTINK CREEK NEAR ANNANDALE, VA & TP & 1.3 & ns \\
\hline 1664000 & S5 & RAPPAHANNOCK RIVER AT REMINGTON, VA & TP & -9.1 & ns \\
\hline 1665500 & S6 & RAPIDAN RIVER AT RUCKERSVILLE, VA & TP & -64.3 & IMPROVING \\
\hline 1671100 & S7 & LITTLE RIVER NEAR DOSWELL, VA & $\mathrm{TP}$ & 21.6 & ns \\
\hline 1673800 & S8 & PO RIVER NEAR SPOTSYLVANIA, VA & TP & -0.3 & ns \\
\hline 1674000 & S9 & MATTAPONI RIVER NEAR BOWLING GREEN, VA & TP & -18.5 & ns \\
\hline 2020500 & $\mathrm{~S} 12$ & CALFPASTURE RIVER ABV MILL CREEK AT GOSHEN, VA & TP & 20.8 & ns \\
\hline 2027500 & S13 & PINEY RIVER AT PINEY RIVER, VA & $\mathrm{TP}$ & -8.4 & ns \\
\hline 2031000 & S14 & MECHUMS RIVER NEAR WHITE HALL, VA & TP & 18.6 & ns \\
\hline 2039500 & S15 & APPOMATTOX RIVER AT FARMVILLE, VA & TP & 11.7 & ns \\
\hline 2041000 & S16 & DEEP CREEK NEAR MANNBORO, VA & $\mathrm{TP}$ & -3 & ns \\
\hline 1626000 & S1 & SOUTH RIVER NEAR WAYNESBORO, VA & Sediment & 5.2 & ns \\
\hline 1628500 & S2 & S.F. SHENANDOAH RIVER NEAR LYNNWOOD, VA & Sediment & 135.1 & DEGRADING \\
\hline 1638480 & S3 & CATOCTIN CREEK NEAR TAYLORSTOWN, VA & Sediment & 17.2 & ns \\
\hline 1654000 & S4 & ACCOTINK CREEK NEAR ANNANDALE, VA & Sediment & -58.4 & ns \\
\hline 1664000 & S5 & RAPPAHANNOCK RIVER AT REMINGTON, VA & Sediment & 19.6 & ns \\
\hline 1671100 & S7 & LITTLE RIVER NEAR DOSWELL, VA & Sediment & 49.7 & ns \\
\hline 2031000 & S14 & MECHUMS RIVER NEAR WHITE HALL, VA & Sediment & -4.5 & ns \\
\hline 2039500 & S15 & APPOMATTOX RIVER AT FARMVILLE, VA & Sediment & 63.7 & ns \\
\hline 2041000 & S16 & DEEP CREEK NEAR MANNBORO, VA & Sediment & 17.4 & ns \\
\hline
\end{tabular}


had expanded to the current network of 64 sites. The regression technique produces a trend adjusted for flow by adjusting for the influences of streamflow and season. This technique is useful in assessing the water-quality changes resulting primarily from resource-management actions. Evaluations of methods and test results indicate the need for continuing improvement in statistical methods to help answer new technical questions about water-quality change. In particular, improvements have been identified to (1) construct sample data sets to more accurately represent concentrations and loads at water-quality monitoring locations, (2) improve the statistical analysis to assess changes in trends over shorter periods of time, (3) better describe the patterns of long-term trends, and (4) improve ways to compare trends and additional watershed information to trends in the tidal waters. New approaches to and improvements in data analysis will be a continual process as data from additional sites are added to the Nontidal Monitoring Network database and new methods are developed to aid in the interpretation of environmental data. A recently developed method to examine concentration, load, and trend over the long term (greater than 20 years) is the "Weighted Regressions on Discharge Time and Season" (WRTDS) (Hirsch and others, 2010). This method allows for consistent estimates of the actual history of concentrations and loads, as well as histories that eliminate the influence of year-to-year variations in streamflow. Application of WRTDS to selected sites in the network in future load and trend evaluations will further enhance the understanding of management actions and changes in water quality, ultimately leading to meeting the load allocations to meet the TMDL for the bay.

\section{Summary}

In 2011, the U.S. Geological Survey completed analyses of loads of, and trends in, nutrients and sediment at 31 and 33 "primary sites" (sites where stormflow was sampled) for two time periods (1985-2010 and 2001-10, respectively), loads of nutrients and sediment at 64 sites for a 5 -year time period (2006-10); and 10-year nutrient and sediment trends at "secondary" sites (16 sites where stormflow was not sampled), as part of the effort to evaluate progress, on an annual basis, toward meeting nutrient and sediment allocation goals. The 64 sites represent an increase of 19 sites from those evaluated in the 2009 data analysis update. The total estimated freshwater streamflow entering the bay in 2010 was 78,280 cubic feet per second, an amount that was defined as "normal" and as being between the 25 th- and 75th-percentile values, as determined by using data from 1937. Regression models indicated no significant trends in streamflow (1985-2010) at the 31 long-term sites.

Streamflow increased from 2009 to 2010 at 28 of the 31 sites where long-term loads and trends were estimated. As a result, combined loads for total nitrogen, total phosphorus, and sediment at the nine River Input Monitoring sites increased
33,120 , and 330 percent, respectively. Total nitrogen loads (178 million pounds) were below the long-term average, total phosphorus loads (13 million pounds) were slightly above the long-term average, and sediment loads (15,500 million pounds) were the third highest since 1990 and well above the long-term average.

Long-term flow-adjusted trends were computed at 31 primary sites in the bay watershed. The three largest monitored rivers (Susquehanna, Potomac, and James) exhibited statistically significant downward (improving) trends in total nitrogen. Twenty-one of the 31 sites indicated improving trends in total nitrogen. For total phosphorus, the farthest downstream monitoring sites on the two largest rivers, the Susquehanna and the Potomac, indicated a nonsignificant trend. Twenty-two of the 31 sites indicated improving trends in total phosphorus. Statistically significant downward (improving) trends in sediment were observed for the Susquehanna and Potomac River Basins. There were nine improving trends and seven degrading trends for sediment.

The USGS, working with its Chesapeake Bay Program partners, developed new trend indicators to provide additional information on all 64 primary sites and 16 secondary sites currently in the Chesapeake Bay Nontidal Water-Quality Monitoring Network, which will assist managers to determine optimal management actions to improve water quality in the Chesapeake Bay watershed to help reach bay-wide standards for water quality and, ultimately, to meet the Total Maximum Daily Load mandated by the U.S. Environmental Protection Agency. Trends were evaluated for a shorter time period (2001-10) at 33 primary sites, and loads and yields were estimated for all 64 primary sites. A comparison between trends computed for 1985 to 2010 and those computed for 2001 to 2010 revealed a reduction in the number of sites exhibiting significant trends from the longer to the shorter time period, and sites with significant degrading trends were seldom the same for the two time periods. The $2001-10$ time period indicated more improving trends than degrading trends.

Trends for the shorter time period were combined with the yields to produce a classification system consisting of 12 categories. The combined indicator revealed that 17 of the 33 primary sites for which the appropriate data were available showed improving water quality for total nitrogen (TN), and 2 sites showed degrading water quality with respect to TN. A general spatial pattern was noted of decreasing yields from north (Susquehanna River Basin) to south (James River Basin). With respect to TN, six sites had both improving trends and low yields, whereas two sites had both degrading trends and high yields. Combined-indicator results for total phosphorus (TP) show that 17 of the 33 primary sites for which the appropriate data were available showed improving trends, and 3 sites showed degrading trends. No general spatial pattern was demonstrated in TP yields, except that of lower yields in the western Potomac River Basin. With respect to TP, two sites showed both improving trends and low yields, whereas five sites showed degrading trends and high yields. Degrading trends were found at more sites than improving 
trends for sediment. Seven of the nine sites with degrading trends in sediment were in the Potomac River Basin, whereas two of the three sites with improving trends were in the Susquehanna River Basin. No discernible spatial pattern was observed for sediment yields. Few significant trends were indicated for the 16 secondary sites. Only improving trends in TN at four sites, improving trends in TP at two sites, and a degrading trend in sediment at one site were reported.

\section{References Cited}

Bue, C.D., 1968, Monthly surface-water input to Chesapeake Bay: U.S. Geological Survey Open-File Report 68-29, 45 p.

Bradu, D., and Mundlak, Y., 1970, Estimation of lognormal linear models: Journal of the American Statistical Association, v. 65 , no. 329 , p. $198-211$.

Cohn, T.A., 1988, Adjusted maximum likelihood estimation of the moments of lognormal populations from type I censored samples: U.S. Geological Survey Open-File Report 88-350, $34 \mathrm{p}$.

Cohn, T.A., Delong, L.L., Gilroy, E.J., Hirsch, R.M., and Wells, D., 1989, Estimating constituent loads: Water Resources Research, v. 25, no. 5, p. 937-942.

Cohn, T.A., Caulder, D.L., Gilroy, E.J., Zynjuk, L.D., and Summers, R.M., 1992, The validity of a simple log-linear model for estimating fluvial constituent loads: An empirical study involving nutrient loads entering Chesapeake Bay: Water Resources Research, v. 28, no. 9, p. 2353-2364.

Gilroy, E.J., Hirsch, R.M., and Cohn, T., 1990, Mean square error of regression-based constituent transport estimates: Water Resources Research, v. 276, no. 9, p. 2069-2077.

Helsel, D.R., and Hirsch, R.M., 2002, Statistical methods in U.S. Geological Survey Techniques of Water-Resources Investigations, book 4, chap. A3, 522 p. (Also available online at $h t t p: / / p u b s . u s g s . g o v / t w r i / t w r i 4 a 3 /$.)

Hirsch, R.M., Moyer, D.L., and Archfield, S.A., 2010, Weighted regressions on time, discharge, and season (WRTDS), with an application to Chesapeake Bay river inputs: Journal of the American Water Resources Association, v. 46 , iss. 5,5 p.

Kammerer, P.A., Garn, H.S., Rasmussen, P.W., and Ball, J.R., 1998, A comparison of water-quality sample collection methods used by the U.S. Geological Survey and the Wisconsin Department of Natural Resources in Proceedings of the National Water-Quality Monitoring Council, National Conference on Monitoring, Reno, Nevada, July 7-9, 1998: Washington, D.C., U.S. Environmental Protection Agency, p. III-259-269.
Langland, M.J., Lietman, L.P., and Hoffman, S., 1995, Synthesis of nutrient and sediment data for watersheds within the Chesapeake Bay drainage basin: U.S. Geological Survey Water-Resources Investigations Report 95-4233, 121 p.

Langland, M.J., Edwards, R.E., and Darrell, L.C., 1998, Yields and trends of nutrients and total suspended solids in nontidal areas of the Chesapeake Bay basin, 1985-96: U.S. Geological Survey Water-Resources Investigations Report 98-17, $60 \mathrm{p}$.

Langland, M.J., Phillips, S.W., Raffensperger, J.P., Moyer, D.L., Landwehr, J.M., and Schwarz, G.E., 2006, Changes in streamflow and water quality in selected nontidal sites in the Chesapeake Bay Basin, 1985-2004: U.S. Geological Survey Scientific Investigations Report 2006-5178, 75 p.

Phillips, S.W., ed., 2002, The U.S. Geological Survey and the Chesapeake Bay-The role of science in environmental restoration: U.S. Geological Survey Circular 1220, 32 p.

U.S. Environmental Protection Agency, 2003, Ambient water quality criteria for dissolved oxygen, water clarity, and chlorophyll-a for the Chesapeake Bay and its tidal tributaries: 903-R-03-002, $231 \mathrm{p}$.

U.S. Environmental Protection Agency, 2004, Establishing a Chesapeake Bay nontidal watershed water-quality network: prepared by the Chesapeake Bay Program's Nontidal WaterQuality Monitoring Workgroup, September 2004, 28 p.

Yochum, S.E., 2000, A revised Load Estimation Procedure for the Susquehanna, Potomac, Patuxent, and Choptank Rivers: U.S. Geological Survey Water-Resources Investigations Report 00-4156, 49 p. 
For additional information, write to:

Director

U.S. Geological Survey

Pennsylvania Water Science Center

215 Limekiln Road

New Cumberland, Pa. 17070

or visit our Web site at:

http://pa.water.usgs.gov/ 
